Prepared in cooperation with the Bureau of Reclamation

\title{
Simulation and Validation of Larval Sucker Dispersal and Retention through the Restored Williamson River Delta and Upper Klamath Lake System, Oregon
}

Scientific Investigations Report 2013-5194 



\section{Simulation and Validation of Larval Sucker Dispersal and Retention through the Restored Williamson River Delta and Upper Klamath Lake System, Oregon}

By Tamara M. Wood, Heather A. Hendrixson, Douglas F. Markle, Charles S. Erdman, Summer M. Burdick, and Craig M. Ellsworth

Prepared in cooperation with the Bureau of Reclamation

Scientific Investigations Report 2013-5194 


\title{
U.S. Department of the Interior SALLY JEWELL, Secretary
}

\section{U.S. Geological Survey \\ Suzette M. Kimball, Acting Director}

\author{
U.S. Geological Survey, Reston, Virginia: 2014
}

For more information on the USGS - the Federal source for science about the Earth, its natural and living resources, natural hazards, and the environment, visit http://www.usgs.gov or call 1-888-ASK-USGS.

For an overview of USGS information products, including maps, imagery, and publications, visit http://www.usgs.gov/pubprod

To order this and other USGS information products, visit http://store.usgs.gov

Any use of trade, firm, or product names is for descriptive purposes only and does not imply endorsement by the U.S. Government.

Although this information product, for the most part, is in the public domain, it also may contain copyrighted materials as noted in the text. Permission to reproduce copyrighted items must be secured from the copyright owner.

Suggested citation:

Wood, T.M., Hendrixson, H.A., Markle, D.F., Erdman, C.S., Burdick, S.M., and Ellsworth, C.M., 2014, Simulation and validation of larval sucker dispersal and retention through the restored Williamson River Delta and Upper Klamath Lake system, Oregon: U.S. Geological Survey Scientific Investigations Report 2013-5194, 34 p., http://dx.doi.org/ 10.3133/sir20135194.

ISSN 2328-0328 (online) 


\section{Contents}

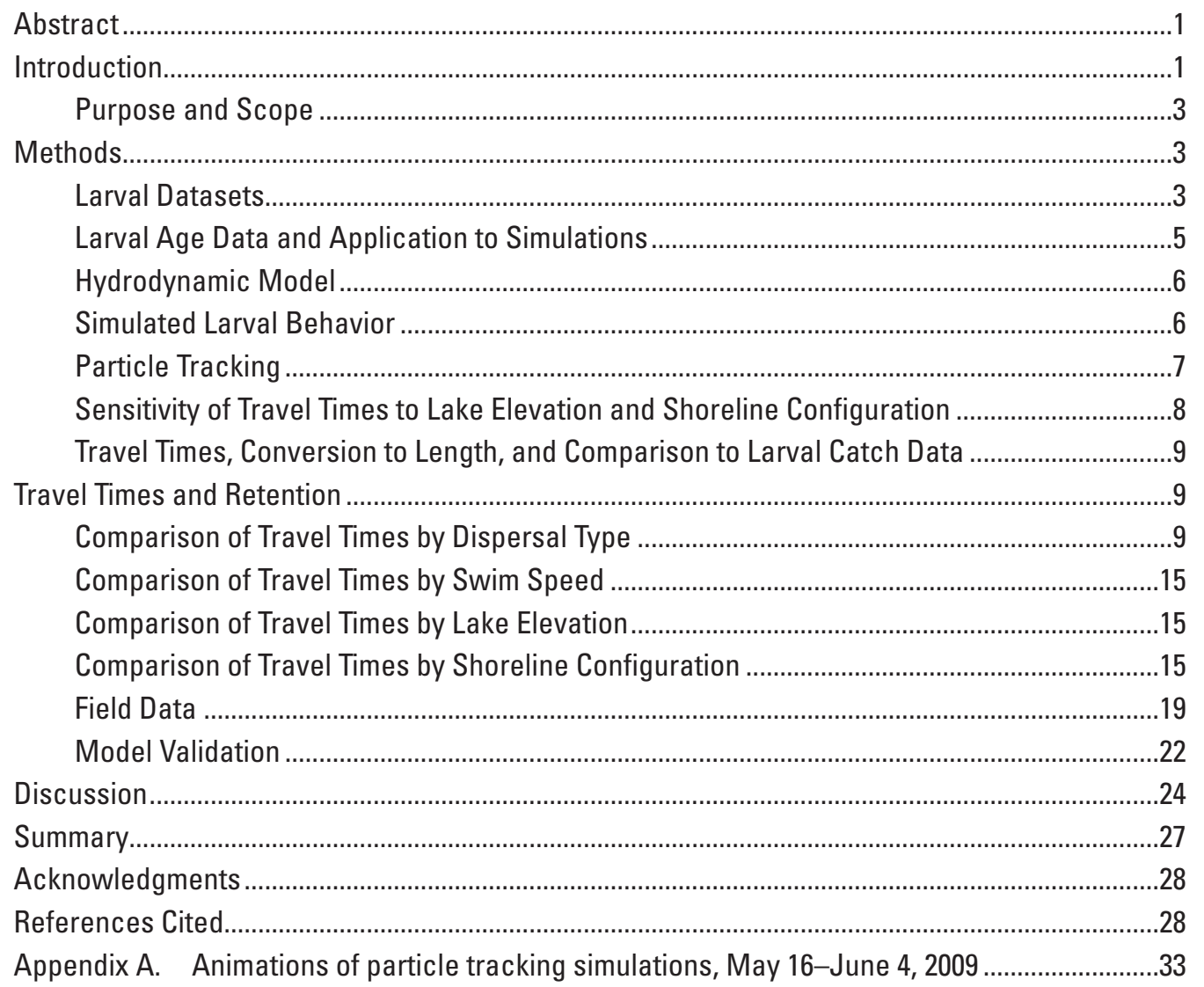




\section{Figures}

1. Map showing fixed larval catch sites after restoration of the Williamson River Delta, Upper Klamath and Agency Lakes, Oregon, 2009.

2. Screen captures showing shoreline configuration in the vicinity of the Williamson River Delta, Upper Klamath and Agency Lakes, Oregon, 2009

3. Graph showing relation between standard length and age as determined from 112 sucker larvae collected from Upper Klamath Lake, Oregon, 2009. .5

4. Screen captures showing simulated current vectors on May 19, 2009, at 0300 hours; and June 1, 2009, at 0300 hours in the Williamson River Delta, Upper Klamath Lake, Oregon

5. Graphs showing number of particles remaining in the particle-tracking simulation as a function of time, after applying a 5 percent per day mortality rate, comparing dispersal scenarios; swim speeds; lake elevations; and shoreline configurations, Upper Klamath Lake, Oregon, May-July 2009

6. Screen captures showing particle simulations of swimming scenario $A$ at midnight on June 4, 2009, for three elevation scenarios in Upper Klamath Lake, Oregon

7. Boxplot showing length distribution of larval suckers in nets and of simulated particles at pop net sites in Upper Klamath Lake, Oregon, May-July 2009

8. Boxplot showing length distribution of larval suckers in nets and of simulated particles at plankton net sites in Upper Klamath Lake, Oregon, May-July 2009

9. Boxplot showing length distribution of larval suckers in nets and of simulated particles at larval trawl sites in Upper Klamath Lake, Oregon, May-July 2009.

\section{Tables}

1. Median travel times for dispersal scenarios from the Modoc Point Road Bridge to fixed larval catch sites in the Williamson River and Upper Klamath Lake, Oregon, May 14-July 24, 2009

2. Summary of larval fish catches by family, species, and collecting agency from selected sites in Upper Klamath Lake and the Williamson River Delta, Oregon, 2009

3. Median standard lengths of larval catches and simulated median standard lengths at fixed sites in Upper Klamath Lake and the Williamson River Delta, Oregon, 2009.

4. Pearson correlation coefficients relating the length of tracked particles to the length of sucker larvae in larval catches from the Williamson River Delta and Upper Klamath Lake, Oregon, 2009 


\section{Conversion Factors and Datums}

\section{Conversion Factors}

Inch/Pound to SI

\begin{tabular}{lccc}
\hline & Multiply & By & To obtain \\
\hline & Length & \\
\hline mile (mi) & 1.609 & kilometer $(\mathrm{km})$ \\
\hline
\end{tabular}

SI to Inch/Pound

\begin{tabular}{|c|c|c|}
\hline Multiply & By & To obtain \\
\hline \multicolumn{3}{|c|}{ Length } \\
\hline millimeter (mm) & 0.03937 & inch (in.) \\
\hline meter $(\mathrm{m})$ & 3.281 & foot $(\mathrm{ft})$ \\
\hline kilometer (km) & 0.6214 & mile (mi) \\
\hline \multicolumn{3}{|c|}{ Area } \\
\hline square meter $\left(\mathrm{m}^{2}\right)$ & $1,550.0$ & square inch (in ${ }^{2}$ ) \\
\hline hectare (ha) & 2.471 & acre \\
\hline \multicolumn{3}{|c|}{ Volume } \\
\hline cubic meter $\left(\mathrm{m}^{3}\right)$ & 35.31 & cubic foot $\left(\mathrm{ft}^{3}\right)$ \\
\hline \multicolumn{3}{|c|}{ Flow rate } \\
\hline millimeter per second (mm/s) & 0.03937 & inch per second (in/s) \\
\hline centimeter per second (cm/s) & 0.3937 & inch per second (in/s) \\
\hline meter per second $(\mathrm{m} / \mathrm{s})$ & 3.281 & foot per second (ft/s) \\
\hline meter squared per second $\left(\mathrm{m}^{2} / \mathrm{s}\right)$ & 10.76 & foot squared per second $\left(\mathrm{ft}^{2}\right)$ \\
\hline
\end{tabular}

\section{Datums}

Vertical coordinate information is referenced to the Bureau of Reclamation datum, which is 1.78 feet above National Geodetic Vertical Datum of 1929 (NAVD 29).

Horizontal coordinate information is referenced to the North American Datum of 1927 (NAD 27).

Elevation and lake level, as used in this report, refer to distance above the vertical datum. 



\title{
Simulation and Validation of Larval Sucker Dispersal and Retention through the Restored Williamson River Delta and Upper Klamath Lake System, Oregon
}

\author{
By Tamara M. Wood', Heather A. Hendrixson2, Douglas F. Markle², Charles S. Erdman², Summer M. Burdick', \\ and Craig M. Ellsworth1
}

\section{Abstract}

A hydrodynamic model with particle tracking was used to create individual-based simulations to describe larval fish dispersal through the restored Williamson River Delta and into Upper Klamath Lake, Oregon. The model was verified by converting particle ages to larval lengths and comparing these lengths to lengths of larvae in net catches. Correlations of simulated lengths with field data were moderate and suggested a species-specific difference in model performance. Particle trajectories through the delta were affected by wind speed and direction, lake elevation, and shoreline configuration. Once particles entered the lake, transport was a function of current speed and whether behavior enhanced transport (swimming aligned with currents) or countered transport through greater dispersal (faster random swimming). We tested sensitivity to swim speed (higher speeds led to greater dispersal and more retention), shoreline configuration (restoration increased retention relative to pre-restoration conditions), and lake elevation (retention was maximized at an intermediate elevation). The simulations also highlight additional biological questions, such as the extent to which spatially heterogeneous mortality or fish behavior and environmental cues could interact with wind-driven currents and contribute to patterns of dispersal.

\section{Introduction}

Deltaic marshes at the mouth of the Williamson River, Oregon, probably were once among the most important habitats for larvae of the endangered Lost River sucker, Deltistes luxatus, and shortnose sucker,
Chasmistes brevirostris, because of their location downstream of known productive spawning grounds. In the 1940s, the delta was diked and drained for agriculture, which resulted in loss of organic matter, soil compaction, and subsidence, particularly in the northern part of the delta. In 1996, The Nature Conservancy purchased the property surrounding the mouth of the Williamson River (fig. 1) and began a large-scale restoration project to reconnect the Williamson River with 2,500 ha of former agricultural land (hereafter referred to as "the delta"). In October 2007, the levees around the northern part of the delta, known as Tulana, were breached, flooding approximately 1,500 hectares (fig. 1). In November 2008, levees around the southern part of the delta, known as Goose Bay, were breached, flooding an additional 1,000 ha. A primary restoration goal was to restore the function of the delta and its wetlands as nursery habitat for the endangered suckers.

Lost River and shortnose suckers are long-lived (as many as $57 \mathrm{yr}$ ) lake dwellers that typically migrate into tributaries of Upper Klamath Lake to spawn in the early spring (Scoppettone and Vinyard, 1991; Terwilliger and others, 2010). In Upper Klamath Lake, the present-day population stronghold for both species, a large portion of each population spawns in the Williamson and Sprague Rivers, and a small group of Lost River suckers spawns at lakeshore springs on the eastern edge of the lake (Janney and others, 2008). After leaving the gravel at the spawning grounds, larvae drift downstream at night with river flow and, prior to restoration, entered Upper Klamath Lake in as little as a day (Cooperman and Markle, 2003). Larval sucker habitat includes nearshore and open water areas of Upper Klamath Lake, but proximity to shore seems most important (Reiser and others, 2001; Cooperman and Markle, 2004; Crandall and others, 2008; Burdick and Brown, 2010).

\footnotetext{
${ }^{1}$ U.S. Geological Survey.

${ }^{2}$ The Nature Conservancy.

${ }^{3}$ Oregon State University.
} 


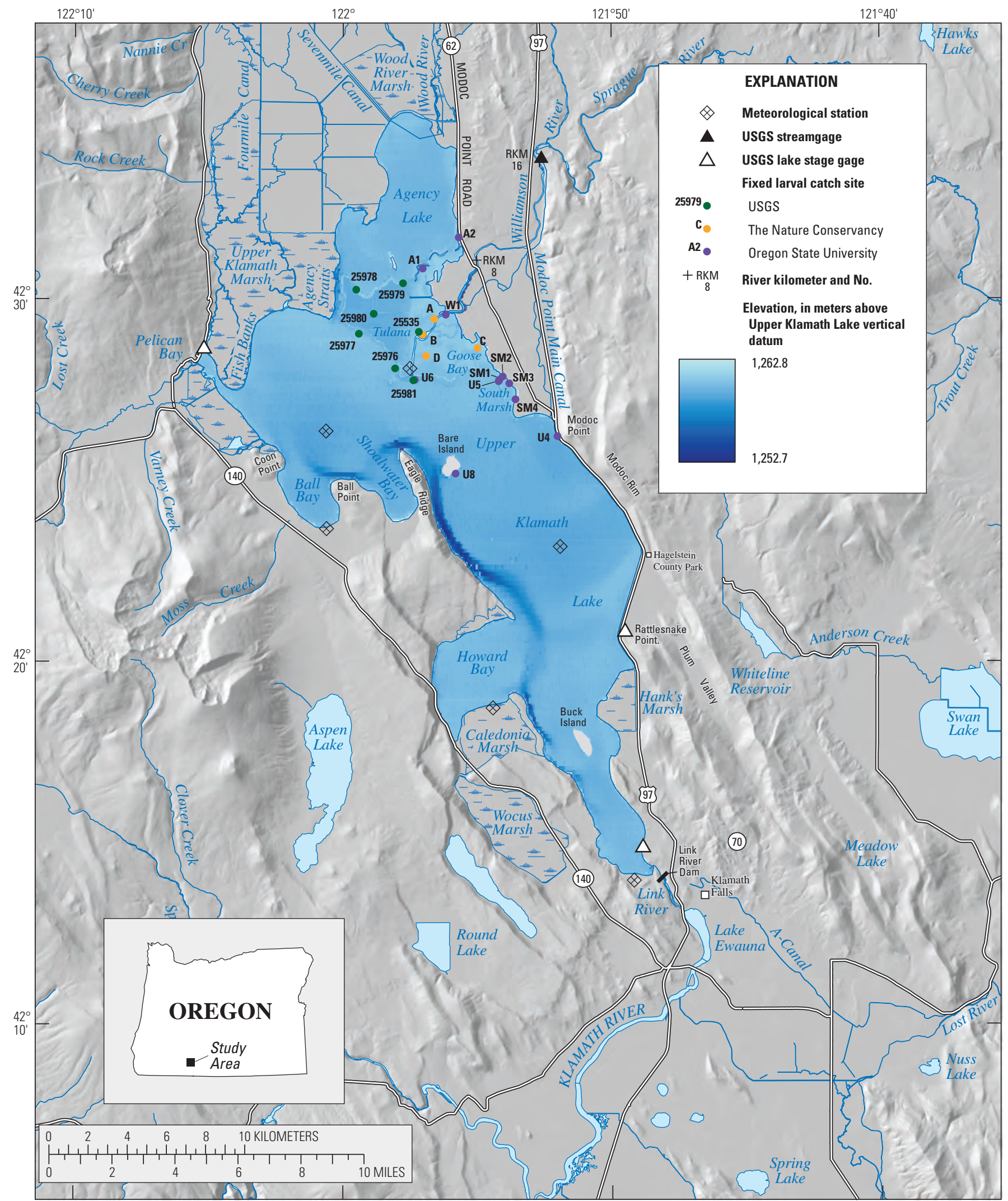

Base modified from USGS and other digital sources, various scales.

Coordinate system is UTM, Zone 10N; North American Datum of 1927

Figure 1. Fixed larval catch sites after restoration of the Williamson River Delta, Upper Klamath and Agency Lakes, Oregon, 2009. 
Restoration of the delta was expected to create complex pathways connecting the lower $5 \mathrm{~km}$ of the Williamson River channel to the lake and to increase travel time from spawning locations to the lake for many larvae (Markle and others, 2009). Over time, the increase in emergent vegetation associated with wetland restoration at the delta is expected to decrease the flow velocity across the wetland and to provide sanctuary from wind turbulence (Cooperman and others, 2010), ample feeding and growing opportunities (Crandall and others, 2008), and predator protection (Markle and Clausen, 2006; Markle and Dunsmoor, 2007). These effects of wetland restoration potentially contribute to lower early-life mortality, less emigration from the lake, stronger year class formation, and aid the recovery of the species.

Field collections are spatially and temporally limited, and a spatially distributed model can provide information at temporal and spatial scales that are unattainable through field sampling. Models also provide iterative visual feedback, with field data providing guidance about model assumptions and the model simulations providing guidance about appropriate field sampling strategies and, when confidence is established, predictions under different scenarios. Models of marine larval dispersal are numerous and have been applied to connectivity between populations (Hare and others, 2002; Nahas and others, 2003; Paris and others, 2009; Ashford and others, 2010; Watson and others, 2010), adaptive sampling (Voss and Hinrichsen, 2003; Pepin and others, 2009), and recruitment prediction (Reyns and others, 2006; Hinckley and others, 2009; Mariani and others, 2010). Examples of models for freshwater larval dispersal are fewer than for marine larval dispersal (Beletsky and others, 2007). For this study, the relevant concepts developed for marine larval dispersal were applied and adapted to a large, shallow lake with a complex spatial geometry in which the water currents are primarily wind-driven, using target species that are endangered and, therefore, rare. Larval dispersal was simulated to gain insight into how the physical configuration of the delta landscape and environmental conditions affect the transport of a larval cohort from spawning to rearing habitat.

\section{Purpose and Scope}

The purpose of this study was to develop and to validate with field data a biophysical model of larval sucker dispersal from spawning grounds through the delta and into the lake. Wood and others (2008) developed a hydrodynamic and heat model for Upper Klamath Lake and Agency Lake (a northern embayment of Upper Klamath Lake), and Wood and others (2012) used an advection-diffusion approach to simulate water currents transporting larval cohorts through the system. The advection-diffusion approach is limited to describing transport of larvae by currents in combination with passive dispersal and, therefore, cannot be used to simulate active dispersal resulting from horizontal swimming.
This report documents an individual-based approach used to simulate the ensemble age of larvae at larval catch sites and, using a length-at-age regression, the estimated lengths were compared to the length distribution of fish captured in nets. The individual-based approach cannot provide concentration information at the spatial and temporal resolution of the advection-diffusion approach, but it has the advantage of allowing the age of individual particles to be tracked through the system, and it allows the spreading of the larvae that is superimposed on the advective transport to be described as active dispersal resulting from horizontal swimming. Thus, this approach is particularly suited to addressing how the ability of the larvae to swim, and to swim in response to certain stimuli, might affect the dispersal of the larvae through the delta. We used the model to understand travel times and pathways through the delta, how those travel times and pathways changed as restoration altered the shoreline configuration in two phases between 2007 and 2009, and how those travel times and pathways changed with assumptions about larval swim behavior. We also used the model to explore how the management of lake elevation at higher or lower stage could alter larval transport. We assessed the model assumptions about dispersal by converting particle ages to fish lengths and comparing the resulting simulated lengths to field data.

\section{Methods}

\section{Larval Datasets}

Oregon State University (OSU), The Nature Conservancy (TNC), and the U.S. Geological Survey (USGS) collected larval catch data in 2009 at both "fixed" sites and "random" sites. Multiple visits to 22 fixed sites (11 OSU sites, 4 TNC sites, and 7 USGS sites; fig. 1) were selected for comparison of simulated results to larval catches, and to describe the spatial pattern of the distribution of simulated particle ages and lengths. Random sites were visited only once per season. Data from fixed (fig. 1) and random sites were combined (fig. 2) for correlating simulated results with larval catches. Most of the OSU sites were located outside the delta and close to lake shorelines. The TNC sites were located in shallow water (less than $1.0 \mathrm{~m}$ deep) in the delta and along the levees. The USGS sites were located in deeper water than the OSU and TNC sites and, therefore, were farthest from shorelines or levees.

Larval data collection and preservation methods are described in detail in Wood and others (2012), and are only briefly described here. Data were collected by OSU during daylight hours with a larval trawl (LaBolle and others, 1985) set close to shore in water up to $1 \mathrm{~m}$ deep. Samples were collected from early April through late July every third week for a total of six sampling surveys. Two replicate samples were collected from each of the 11 OSU fixed sites used in this work (ig. 1). 


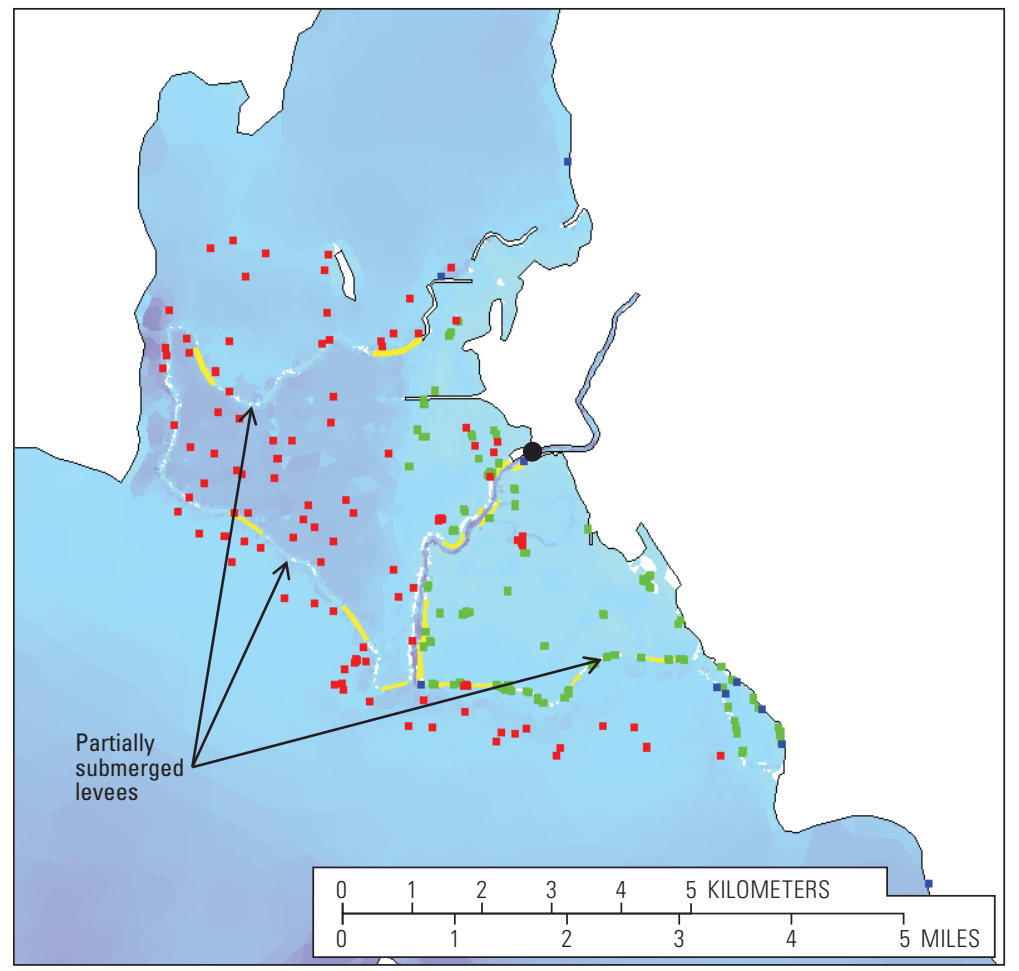

EXPLANATION

Levee breeches

Plankton net sites (USGS)

- Pop net sites (TNC)

- Larval trawl sites (OSU)

Location of insertion of numerical particles Depth, in meters

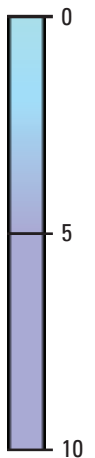

Figure 2. Screen captures showing shoreline configuration in the vicinity of the Williamson River Delta, Upper Klamath and Agency Lakes, Oregon, 2009.

Data were collected by TNC during daylight hours, with 2.56- $\mathrm{m}^{2}$ pop nets set in water as much as $1 \mathrm{~m}$ deep. Two to four "replicate" samples were collected at each site, usually within an hour of each other. The samples were considered replicates for this study even though one net might have been set in emergent or submerged vegetation while another net nearby might have been set on substrate with no vegetation, and the depth also sometimes varied between the replicate nets. Four fixed sites were visited weekly, two in the northern delta and two in the southern delta (fig. 1) along with the random sites (fig. 2).

USGS used diurnal plankton net tows to collect larvae from the top of the water column by towing the net parallel to a boat at approximately $1 \mathrm{~m} / \mathrm{s}$ for 3-5 min or until algae began to clog the mesh. One, two, or three replicate tows were done at each site. Plankton net samples used in this study were collected at random sites (fig. 2) and at seven fixed sites (ig. 1).
USGS also collected samples at the upstream bounary site of the model (fig. 2), which is at Modoc Point Road Bridge, 7.4 river kilometers upstream of the historical mouth of the Williamson River. Samples were collected from the thalweg by deploying a weighted plankton net equipped with a flow meter from the bridge for 10-min sets. Samples were collected from March 23 to July 17, three times each week, between sunset and 5-8.25 hours after sunset. Additional sampling details are in Ellsworth and others (2009).

Samples were either fixed in 10-percent formalin and later transferred to 50-percent isopropanol or preserved directly in 70-95-percent ethanol. Because some samples were initially fixed in formalin and others were placed directly into ethanol, differential larval shrinkage may have introduced some bias in the results. However, the 1-2 percent difference in shrinkage between formalin and ethanol was considered trivial for our analyses and no corrections were made. Larval species were identified according to methods described in Wood and others (2012). 


\section{Larval Age Data and Application to Simulations}

Sampling methods targeted larvae-sized fishes, so to reduce problems with reduced gear efficiencies for larger larvae, all analyses were restricted to larvae with a standard length (total length minus tail length) of 10-19 mm. All references to fish lengths used in this study refer to standard lengths. We aged 112 sucker larvae with lengths between 11.5 and $19.0 \mathrm{~mm}$ from the 2009 TNC samples (Erdman and Hendrixson, 2010), following the methods of Terwilliger and others (2003). The age estimate (in days) of each larva was based on median lapillus otolith ring counts from three blind reads by the same reader of each otolith. The resulting relation between length and age was age $=4.55 \times$ length 44.86 (coefficient of determination $\left[\mathrm{R}^{2}\right]=77.1$ percent) where length is the standard length of the fish in millimeters, and age is the estimated age of the fish in days. The intercept is near or within the range of hatch sizes reported for Lost River suckers (9.6-10. $4 \mathrm{~mm})$ and shortnose suckers (7.0-9.6 mm) (Hoff and others, 1997). The equation for age as a function of length was converted to a length-at-age relation (length = $9.87+0.22 \times$ age; fig. 3 ) in order to determine the swim speed associated with individual particles within the model and to convert particle ages to lengths for comparison to field data.

The age of all particles was assumed the same at the time of insertion into the model grid, and was determined as the sum of the age at the Modoc Point Road Bridge and the travel time between the bridge and the location where particles were inserted into the grid (fig. 2). The estimated age (8.3 d) at the Modoc Point Road Bridge was calculated from the median standard length (11.7 mm; Ellsworth and Martin [2012]) of 8,695 sucker larvae caught there, using the regression equation for age as a function of length, age $=4.55 \times$ length -44.86 . Travel time between the Modoc Point Road Bridge and the domain boundary was determined with numerical travel time experiments in which a tracer, simulating nighttime larval sucker behavior, was initialized at the Modoc Point Bridge and allowed to travel down the Williamson River channel. The travel time experiments used the range of streamflows measured between May 18 and June 7, 2009, the span of time during which most of the particles were inserted. Travel time was $1.0 \mathrm{~d}$, resulting in an initial age of $9.3 \mathrm{~d}$ for each particle inserted into the simulation.

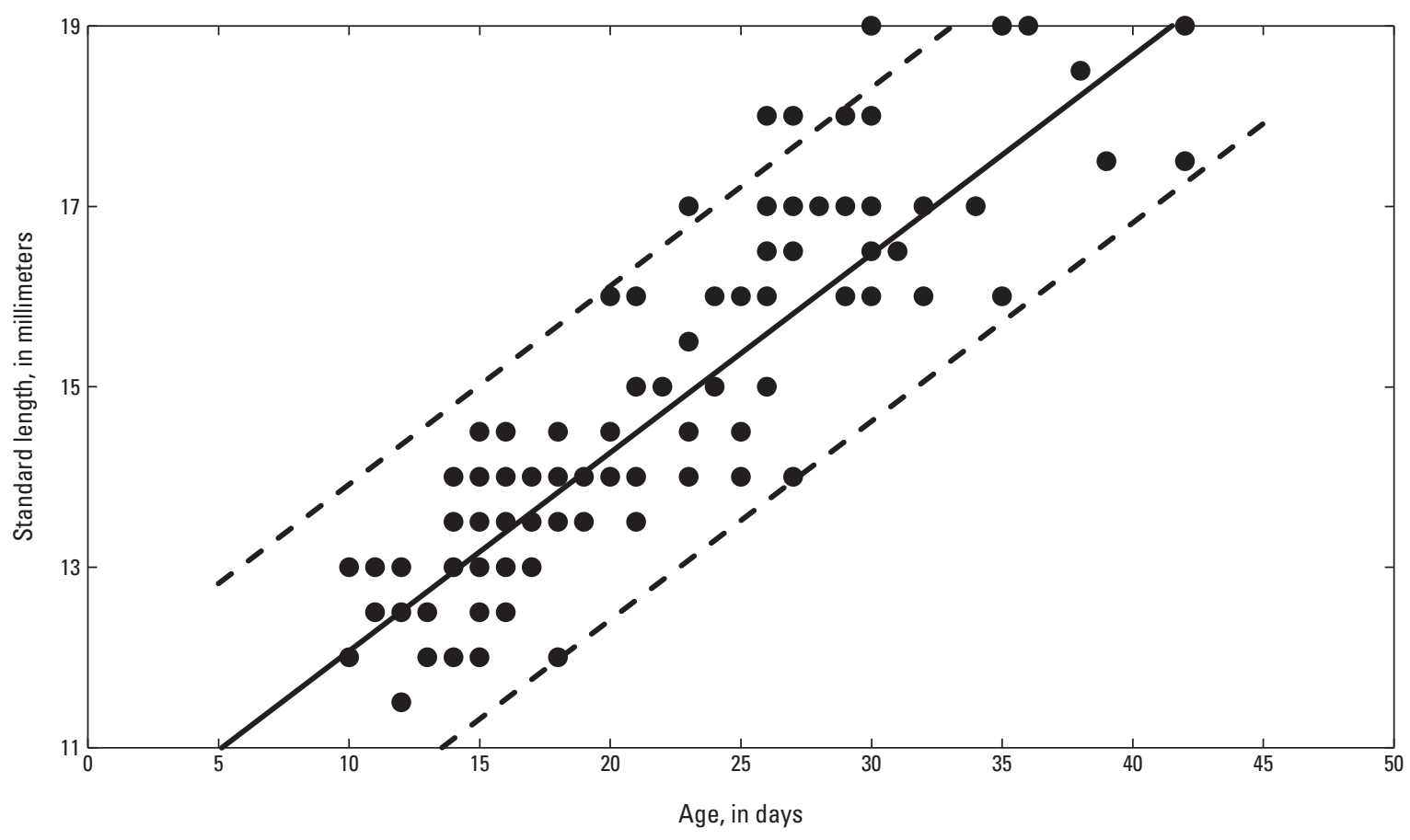

Figure 3. Relation between standard length and age as determined from 112 sucker larvae collected from Upper Klamath Lake, Oregon, 2009. Best linear fit to the data and 95-percent confidence intervals are shown. 
The span of inference for the model was limited to fish aged less than $46 \mathrm{~d}$ (20 mm standard length, based on the length-at-age relation). The 20-mm standard length and 46-d limit correspond to an age when most individuals would be approaching the juvenile stage. Given these considerations, particles were tracked individually from $9.3 \mathrm{~d}$ of age until they either left the domain through the outflow boundary at the Link River (fig. 1) or reached $46 \mathrm{~d}$ of age. Therefore, the maximum time that a particle was tracked in the model domain was $36.7 \mathrm{~d}$. Retention of particles in the lake was measured by calculating the ratio of the number of particles that had left the domain at the Link River at the end of the simulation to the number that had reached the 46-d age limit $\left(\mathrm{R}_{\mathrm{E} / \mathrm{A}}\right)$.

Swim speed is a function of fish length, and several relations were used to determine model inputs. The maximum burst speed for razorback sucker larvae with a standard length of $19 \mathrm{~mm}$ has been determined to be $464 \mathrm{~mm} / \mathrm{s}$ or 24 body lengths (BL) per second (BL/s) (Wesp and Gibb, 2003). Prolonged swim speeds ( 50 percent of fish held this speed for $1 \mathrm{hr}$ ) were determined to average $5.8 \mathrm{BL} / \mathrm{s}$ (range of 5.3 to $6.5 \mathrm{BL} / \mathrm{s}$ ) for robust redhorse sucker larvae with a standard length of 13.1-20.4 mm (Ruetz and Jennings, 2000). No historical observations on sustained cruising speeds (speeds that can be maintained indefinitely) were found for larval suckers. However, herring and anchovy larvae are similarly elongate, and their sustained speeds are well documented and potentially comparable to sucker larvae. Using the regression in Blaxter and Hunter (1982), larvae with a standard length of $10-19 \mathrm{~mm}$ would have sustained cruising speeds of $1.2 \mathrm{BL} / \mathrm{s}$. Therefore, an intermediate speed of $3.5 \mathrm{BL} / \mathrm{s}$ was chosen for most simulations and sensitivity to swim speed was investigated using sustained (1.2 BL/s) and prolonged swim speeds $(5.8 \mathrm{BL} / \mathrm{s})$. Swim speeds were applied by converting particle ages to body length using the length-at-age regression and calculating swim speed from body length.

Mortality is strongly size-dependent and difficult to measure in larval fishes (Houde and Bartsch, 2009). According to Houde and Zastrow (1993), the mean mortality rate $\left(K_{M}\right)$ for freshwater fish larvae is 14.8 percent per day. First-order estimates for sucker larvae from the Upper Klamath Lake, which are longer than many freshwater fish larvae at hatch, ranged from 8.2 to 2.6 percent per day (Markle and others, 2009). Because of the variability in these estimates, an intermediate $K_{M}$ was used that corresponded to a loss of 5 percent of the population each day $\left(K_{M}=0.051 / \mathrm{d}\right)$.

\section{Hydrodynamic Model}

The UnTRIM hydrodynamic model solves the governing equations for flow and transport on an orthogonal unstructured grid using the efficient and stable algorithms of Casulli and Zanolli (2002). The details of the three-dimensional Upper Klamath Lake model and its calibration and validation are provided for 2005 and 2006 in Wood and others (2008). The one-layer version of the hydrodynamic model that was used in this study, including determination of the flow boundary conditions at the tributaries and the lake outlet, and initialization of the lake elevation, is described in Wood and others (2012). The wind forcing at the surface of the lake was obtained from a spatial interpolation of 10-min data collected at six meteorological sites, and the elevation of the lake was determined as a weighted average of three stage gages on the shoreline (fig. 1). Three versions of the numerical grid were used in this study to investigate the sensitivity of travel times to the shoreline configuration: (1) prior to the start of restoration, (2) after the first phase was completed (reconnection to the lake of the northern part of the delta only), and (3) after restoration was complete (reconnection of both the northern and southern parts of the delta).

\section{Simulated Larval Behavior}

To simulate sucker larvae, numerical particles were inserted into the model domain and tracked individually from the time they were inserted until they either left the domain through the outflow boundary at the Link River (fig. 1) or reached $46 \mathrm{~d}$ of age, the span of inference for our model. Simulations spanned the period May 14July 24, 2009. Dispersal of particles was simulated assuming passive dispersal and three types of active dispersal with swimming behavior.

Boundary conditions for a numerical tracer entering the delta were based on larval sucker-density data collected in the thalweg at the Modoc Point Road Bridge using the method described in Wood and others (2012). Particles representing individual larvae were inserted along a transect across the river channel, about $175 \mathrm{~m}$ upstream of the point where the channel enters the delta (fig. 2). At each model time step, the concentration of the tracer representing larval density was determined at the center of this transect, and the number of particles inserted into the model domain at that time step was in constant proportion to the tracer concentration. Using this method, 3,748 particles were inserted during the 70-d simulation in 2009, with a temporal pattern that mimicked the temporal pattern of the total density of sucker larvae in 
the drift at Modoc Point Road (Ellsworth and Martin, 2012). ("Drift" refers to the organisms suspended in the current of a stream.) Each dispersal scenario was simulated four times, and the particles were combined, so that nearly 15,000 particles were used to calculate travel times and to compare with field data for each scenario.

The application of fish behavior to larval fish dispersal models is complex (Leis, 2007), and, without specific information on swimming orientation and sensory abilities, we used a simplified approach that was designed to explore how different types of swimming behavior would be manifested in the larval dispersal patterns. Nighttime drift behavior was applied only to particles in the channel of the Williamson River. Lacking specific knowledge of environmental stimuli that trigger nighttime drift, particles in the channel were held in place from sunrise to sunset and tracking was resumed at sunset.

Horizontal swimming was incorporated as both non-oriented (randomized) and oriented swimming. Advective transport was determined by the sum of the depth-averaged velocity provided by the model simulation and a random component intended to mimic swimming behavior. Simulation of swimming required swim speed, $\mu_{s}$, the length of time during which the speed was maintained before a change in direction occurred, $\tau_{s}$, and the angle of the swim vector, $\theta_{s}$. Swim speed was a function of length, which was determined from the length-at-age regression.

Oriented swimming in fish larvae can be complex, often highly directional, and may or may not be influenced by cues such as light, currents, or shorelines (Trnski, 2002; Leis and Carson-Ewart, 2003). In this study currents simulated by the hydrodynamic model were used as cues. The swimming direction in some fish larvae is not influenced by current direction (Leis and Carson-Ewart, 2003), but it can be in some species and life stages (Champalbert and Marchand, 1994). Because there is evidence that larval retention in the lake, and presumably in the delta, is an important predictor of juvenile recruitment success (Markle and others, 2009), the effect of rheotaxis on biophysical retention was investigated. Oriented swimming was simulated as a tendency by the fish to swim at an angle approximately aligned with the current and directed downstream with the current. Oriented swimming was simulated to occur only at night (between sunset and sunrise). Lacking information on larval fish, oriented swimming was defined to occur at current speeds greater than or equal to $5 \mathrm{~cm} / \mathrm{s}$, which was the threshold determined for rheotaxic behavior in juvenile sole with a standard length of 9-14 mm (Champalbert and Marchand, 1994). The angle of swimming $\theta_{s}$ changed on a time step equal to the time step of the hydrodynamic model, such that $\tau_{s}$ was equal to $2 \mathrm{~min}$.

\section{Particle Tracking}

The particle-tracking algorithm that was used to track both passive and biophysical particles has the general form:

$$
\frac{d x}{d t}=u(x, y, t)+u_{r}(x, y, t)
$$

and

$$
\frac{d y}{d t}=v(x, y, t)+v_{r}(x, y, t)
$$

where

$u$ and $v$ are the eastward and northward components of the fluid velocity (depth-averaged, as the hydrodynamics are supplied by a twodimensional model); and

$u_{r}$ and $v_{r}$ are the eastward and northward components of a randomized addition to the fluid velocities, intended to simulate passive dispersal by turbulent eddies in the case of the passively transported particles, or larval swim velocities in the case of biophysical particles.

The particle tracking equations were solved using the same time step that was used in the hydrodynamic model to update the advective velocities (2 min).

For passive dispersal, which is designated scenario A, the randomized components are based on a two-dimensional random displacement model in which the eddy diffusivity is constant:

$$
\begin{aligned}
& u_{r}=\left(\frac{2 D}{d t}\right)^{1 / 2} Q_{x} \\
& v_{r}=\left(\frac{2 D}{d t}\right)^{1 / 2} Q_{y}
\end{aligned}
$$

where

$Q_{x}$ and $Q_{y}$ are normally distributed random numbers with a mean of zero and a standard deviation of 1 (Brickman and others, 2008); and $D$ is the eddy diffusivity. 
In practice, the random numbers are calculated from two other random numbers uniformly distributed from 0 to 1 using the Box-Muller transformation (Box and Muller, 1958). When particle tracking carried a particle across a solid boundary, a new pair of random numbers $Q_{x}$ and $Q_{y}$ were chosen and a new set of the components $u_{r}$ and $v_{r}$ were calculated, until the particle tracking did not result in the particle being carried across a solid boundary. This was attempted up to 100 times, at which point the particle was considered "lost" and was no longer tracked, but very few particles were lost in this way. Eddy diffusivity, $D$, was set to a value of $0.1 \mathrm{~m}^{2} / \mathrm{s}$, consistent with the value used in the advection-diffusion approach of Wood and others (2012).

Active dispersal was simulated in scenarios B, C, and D. In these scenarios, swimming behavior was simulated by replacing the randomized components of velocity for passive particles with components in the form:

$$
u_{r}^{\prime}=u_{r}(x, y, t)+\left(\sigma_{s} \times Q_{x}+\mu_{s}\right) \times \cos \left(\theta_{s}\right)
$$

and

$$
v_{r}^{\prime}=v_{r}(x, y, t)+\left(\sigma_{s} \times Q_{y}+\mu_{s}\right) \times \sin \left(\theta_{s}\right)
$$

where

$\sigma_{s}$ is the standard deviation of the larval swim speed, which was assumed proportional to the mean larval speed and set to 0.3 times $\mu_{s}$.

In simulations of dispersal that included nighttime-only drift behavior, if the particle was in the Williamson River channel between sunrise and sunset, the particle was not allowed to move, in order to simulate nighttime-only drift. Two types of swimming behavior were simulated by the choice of $\theta_{s}$.

For scenarios $\mathrm{B}$ and $\mathrm{C}$, which assumed random swimming, the direction of swimming $\theta_{s}$ was randomly chosen from a uniform distribution between $-\pi$ and $\pi$. In the oriented swimming scenario $D$, the angle of the water current $\theta_{c}$ at the starting position of the particle was determined at the beginning of each tracking step. Oriented swimming occurred only between sunset and sunrise and only when the current speed was greater than $5 \mathrm{~cm} / \mathrm{s}$. During the day and anywhere that the current speed was less than $5 \mathrm{~cm} / \mathrm{s}$, swimming was non-oriented. When swimming was oriented, swim direction was sampled from a von Mises distribution (Best and Fisher, 1979) centered on $\theta_{c}$ that provided a moderate preference for alignment with the current (approximately 75 percent of the distribution was within $\pm 30^{\circ}$ of $\theta_{c}-\pi$ and 97 percent of the distribution was within $\pm 60^{\circ}$ of $\theta_{c}-\pi$ ). If particle tracking carried a particle across a solid boundary, it was retained at the shoreline for that time step, and not moved. At the next time step, tracking of all particles, including those retained at the shoreline, resumed as usual. Therefore, when swimming behavior was simulated, particles were never "lost" from the simulation.

Movement in the Williamson River channel was assumed to occur throughout the day in scenario B, but was assumed to occur only at night in scenarios C and D. Nighttime-only drift was simulated in scenarios $\mathrm{C}$ and $\mathrm{D}$ by storing the location of any particles in the Williamson River channel at sunrise. Tracking of those particles stopped at sunrise and resumed at sunset.

\section{Sensitivity of Travel Times to Lake Elevation and Shoreline Configuration}

Dispersal scenario C was used to investigate the effect of lake elevation on particle dispersal through the delta and travel times by simulating two additional initial lake elevations. The first additional initial elevation was $0.19 \mathrm{~m}$ higher than the recorded initial elevation, which meant that the lake was at full pool at the maximum elevation achieved during the simulation (scenario $\mathrm{C}+^{+}$. The second additional initial elevation was a similar distance $(0.25 \mathrm{~m}$ ) lower (scenario C-) than the recorded starting lake elevation, which was 1,262.7 $\mathrm{m}$ above the Upper Klamath Lake Vertical Datum. Subsequent changes in lake elevation relative to the starting elevation were identical for scenarios C, C+, and C-. Scenarios C+ and C- each were simulated once, so 3,748 particles were used to calculate travel times for each of these scenarios.

Dispersal scenario $\mathrm{C}$ also was used to better understand the changes in particle dispersal attributable to changes in the shoreline that occurred as restoration proceeded between 2007 and 2009. To do this, all boundary and forcing conditions remained as observed in 2009, but simulations of particle tracking were completed for the shoreline configuration as it existed in 2007 (before restoration, scenario C-2007) and 2008 (northern delta only flooded, scenario C-2008). The results of C-2007 and C-2008 were compared to the simulation completed for the shoreline configuration as it existed starting in 2009 (northern and southern parts of the delta flooded, scenario C). Scenarios C-2007 and C-2008 each were simulated once, so 3,748 particles were used to calculate travel times for each of these scenarios. 


\section{Travel Times, Conversion to Length, and Comparison to Larval Catch Data}

The median travel times to the fixed larval catch sites (fig. 1) were determined by sampling the particles in the simulation every $6 \mathrm{hr}$. All particles located within a circle of radius $75 \mathrm{~m}$ centered on each fixed site were identified, and the ages of those particles were compiled. All particle ages compiled at each site were combined to create a travel-time distribution at that site, and the median value was determined.

To compare model simulations to field data, particle ages were first converted to fish standard lengths using the lengthat-age relation. All references to simulated lengths used in this study refer to standard lengths. Then, mortality was applied to the particles as a post-processing step, at a rate of 0.051/d. To simulate mortality at this rate, 5 percent of the particles in the domain at midnight on each simulation day were randomly chosen and deleted from that time forward. The process was repeated for each simulation day. The median lengths at the fixed larval catch sites (fig. 1) were determined by sampling the particles remaining in the simulation after mortality was applied and combining all particle lengths collected at each site to create a length distribution at that site. Simulated length distributions were compared graphically to the larval catch length distributions (all sample dates combined) at the fixed sites where at least 10 suckers were captured during the season.

Simulated particle lengths were compared to the lengths of fish captured in individual nets at random and fixed field sites by pairing field and simulation data, and calculating a linear correlation coefficient. All particles located within a $150 \mathrm{~m}$ radius of a field site, up to 1 hour before and after net sampling, were identified and their median age was calculated. The set of paired values of particle and larval median lengths were compared using a Pearson R correlation coefficient for each swimming scenario. This analysis was done with larval catches from all gear types combined and with larval catches from each of the three gear types separated. This analysis also was done by separating larval catches (all gear types combined) into small (fish length $<13 \mathrm{~mm}$ ), medium (fish length $\geq 13 \mathrm{~mm}$ and $<16 \mathrm{~mm}$ ), and large (fish length $\geq 16 \mathrm{~mm}$ and $\leq 19 \mathrm{~mm}$ ) fish. The correlation analysis also was done separately for particles inserted into the domain prior to and after June 2 in order to analyze separately particles representing (predominantly) Lost River sucker larvae prior to June 2 and (predominantly) shortnose sucker larvae after June 2.

\section{Travel Times and Retention}

Winds were predominantly from the west to the northwest during the 2009 simulation period between May 14 and June 10, as is typical for the season, but variability in wind direction and speed over this period was still important. The first pulse of larvae, predominantly Lost River sucker larvae, entered the delta between May 18 and May 21, with a peak on May 18 . Winds were strong (predominantly $6-8 \mathrm{~m} / \mathrm{s}$ ) and from the west-northwest. The second pulse, comprising both Lost River and shortnose sucker larvae, entered the delta between May 29 and June 1, with a peak on June 1 . Winds were weaker (mostly $2-4 \mathrm{~m} / \mathrm{s}$ ) and primarily from the north. Because of this difference in the wind velocity, water currents coinciding with the entry of each pulse into the delta were different: during May 18-21, currents were strong and to the southeast across the southern delta; during May 29June 1, currents were weaker and more variable in direction (fig. 4). The difference in the water currents during the period associated with the entry of each of the two larval pulses into the delta was reflected in the travel times of particles from the upstream boundary to the outlet. The cohort of the particles inserted at the upstream boundary on May 18 exited the lake at Link River on May 30, 12 days later, whereas the cohort of the particles inserted at the upstream boundary on June 1 exited the lake on June 22, 21 days later.

\section{Comparison of Travel Times by Dispersal Type}

Travel times were fastest (1.1-4.3 d) to fixed sites in and near the Williamson River channel on both sides of the delta (table 1, scenario C). Travel time to sites farther away from the Williamson River channel in the northern (USGS 25980) and southern (TNC C) delta was 9.4 and $7.2 \mathrm{~d}$, respectively (table 1, scenario C). Within and near the Williamson River channel, travel times were a function of distance from the upstream model boundary and increased from $1.1 \mathrm{~d}$ at TNC A to $8.0 \mathrm{~d}$ at OSU U6 at the mouth of the Williamson River. Travel times were slower (10.7-13.9 d; table 1, scenario C) to fixed sites in Upper Klamath Lake northwest of the river mouth, and slower still to sites in Agency Lake (15.2-19.5 d; table 1, scenario C). Compared to travel times to sites in Upper Klamath Lake northwest of the river mouth, faster travel times to sites southeast of the river mouth (8.6-9.9 d; table 1, scenario C) indicate that particles were transported along relatively direct pathways across the southern delta and southeast along the shoreline with the currents. 


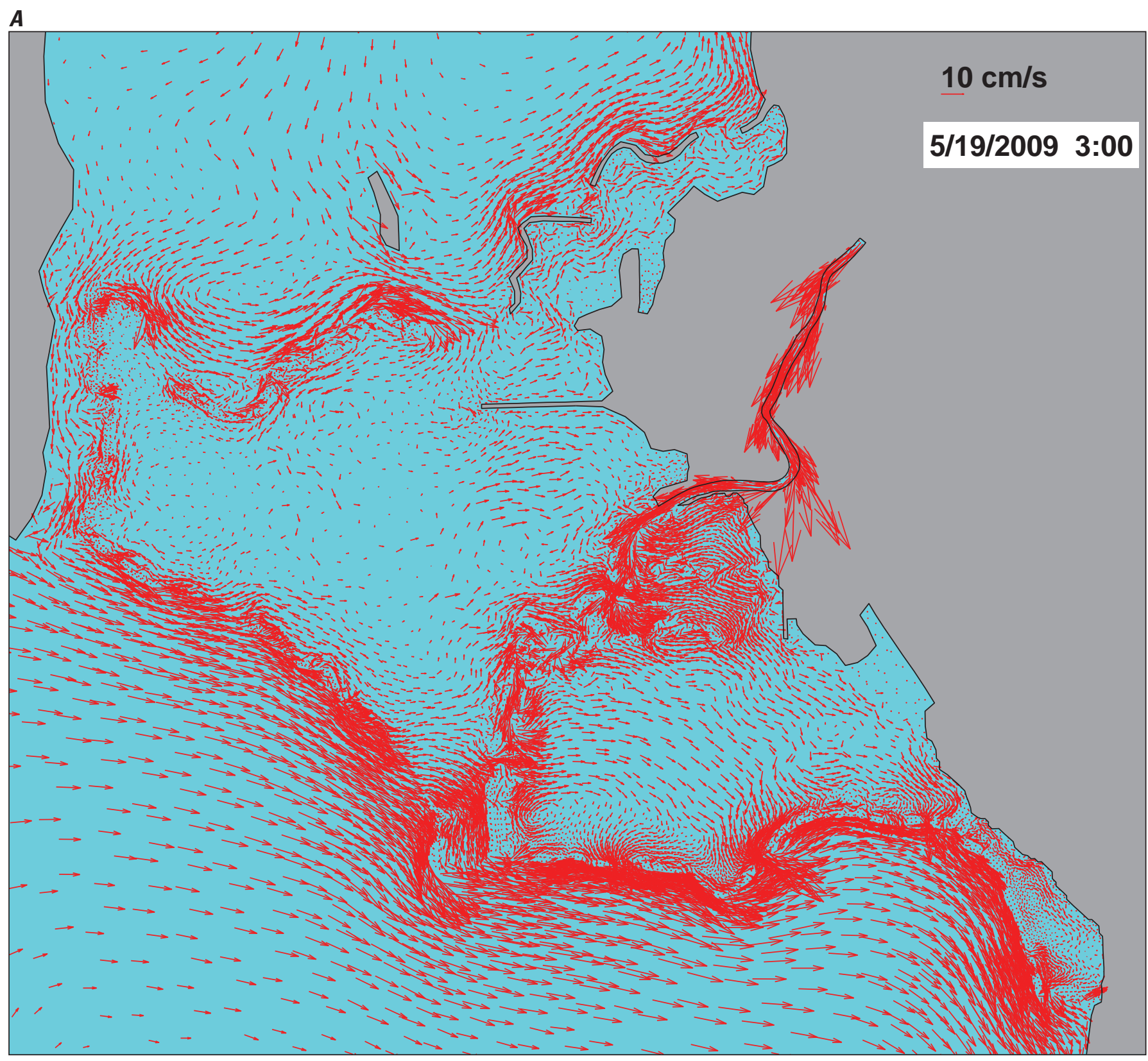

Figure 4. Screen captures showing simulated current vectors on (A) May 19, 2009, at 0300 hours; and (B) June 1, 2009, at 0300 hours in the Williamson River Delta, Upper Klamath Lake, Oregon. 


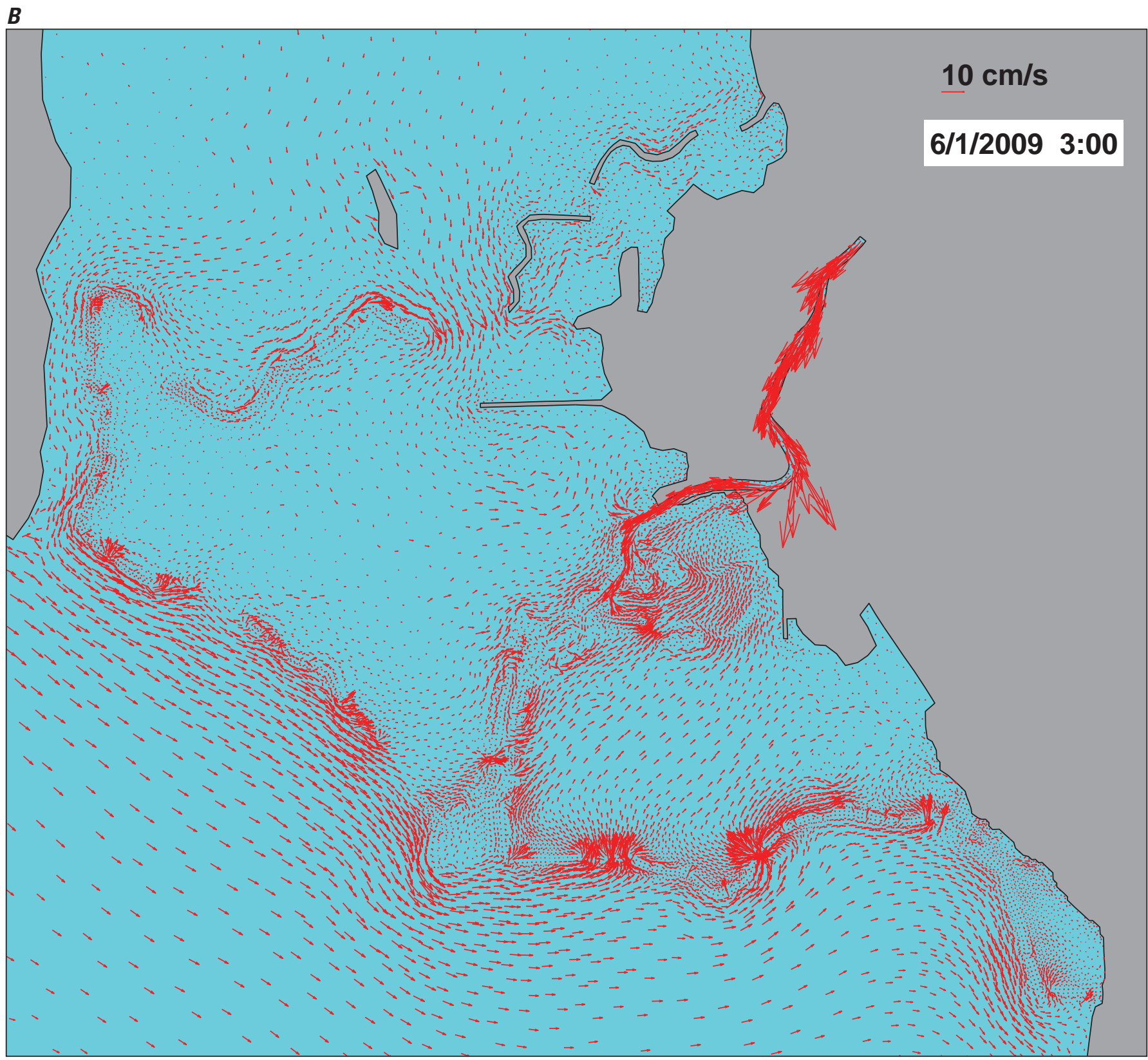

Figure 4.-Continued 


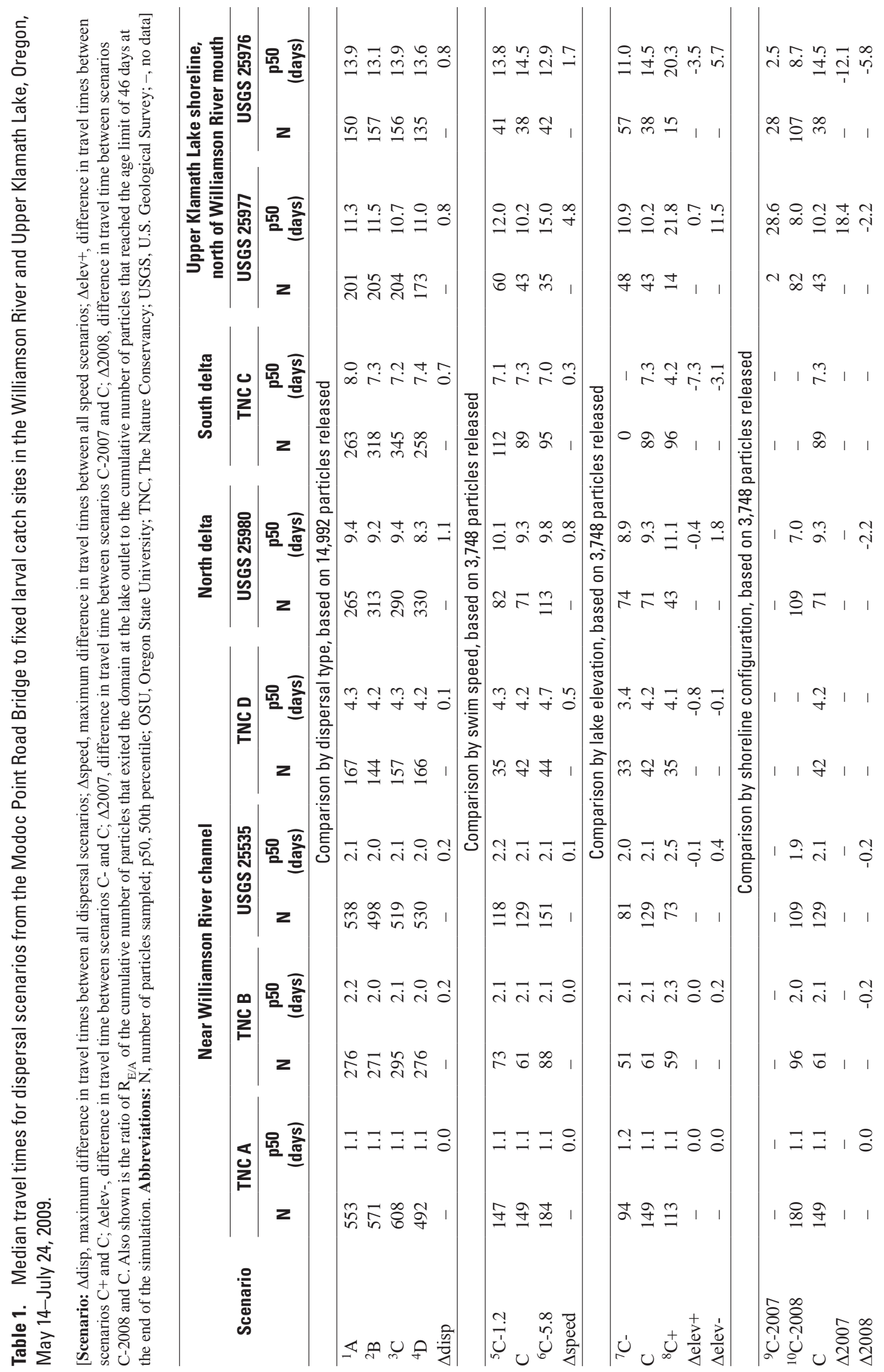




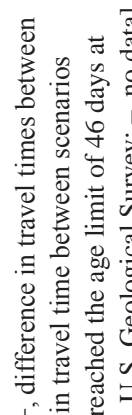

告

可证

调害远

해 $\infty$ 淽

政

نํ.

政

可

要

8 造

论

E

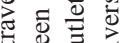

$\Xi$ 疮官

8 즌

进

冓

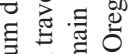

界 $\Xi$ 항

吼

过氙

के

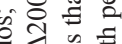

要

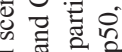

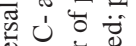

잉

示鸪言

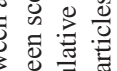

造范

要过

自焉直

总远

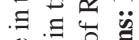

政

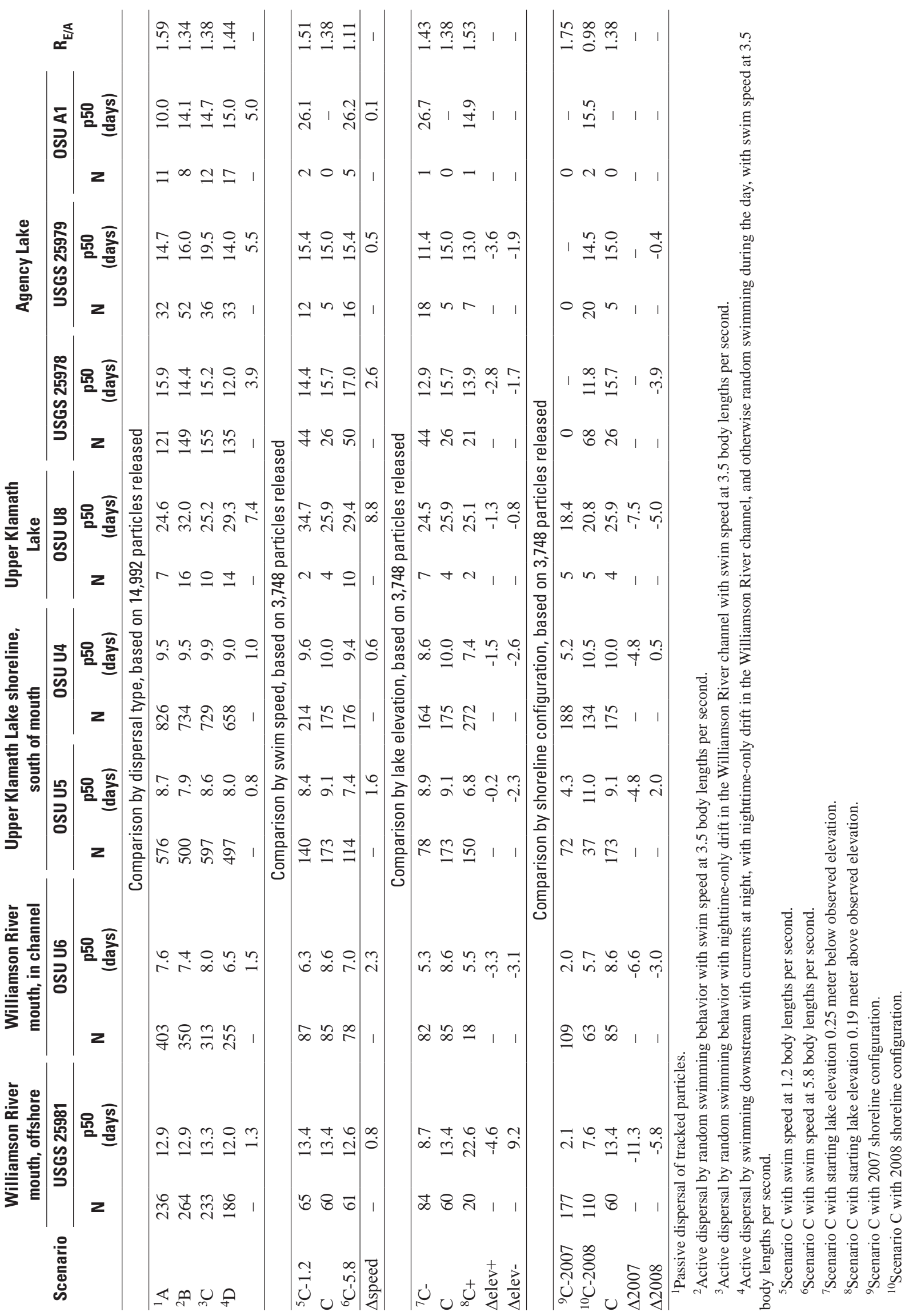


Travel times to sites in Agency Lake and to sites northwest of the river mouth in Upper Klamath Lake were slower than travel times to sites at comparable or greater distances to the southeast because particles arrived at those sites by way of complex pathways. The travel time to site USGS 25981 offshore of the Williamson River mouth was more than $5 \mathrm{~d}$ greater than the travel time to site OSU U6 in the channel at the river mouth (table 1, scenario C). Particles exiting the river mouth head primarily southeast, so that the slower travel times to the site offshore indicate that particles came through the northern delta rather than directly through the river mouth. Finally, the slowest travel time (25.2 d; table 1, scenario C) was for particles captured at Bare Island (OSU U8) and indicated transport by the lakewide gyre.

The difference in travel times simulated by dispersal scenarios A-D varied spatially. At sites reached by relatively straight pathways close to the Williamson River channel (TNC A, B, and D, and USGS 25535; table 1) the maximum difference in travel time between dispersal scenarios was small $(\leq 0.2 \mathrm{~d})$. At other sites in the delta and along the shoreline of Upper Klamath Lake, the difference in travel times simulated by the dispersal scenarios was between 0.7 and $1.5 \mathrm{~d}$. At the mouth of the Williamson River, the difference in simulated travel times was $1.5 \mathrm{~d}$ in the channel and $1.3 \mathrm{~d}$ offshore. The slowest travel time at the mouth was simulated by scenario $\mathrm{C}$, in which the particles did not drift in the river channel during the day, but dispersed passively at night, and the fastest travel time was simulated by scenario $\mathrm{D}$, in which the particles did not drift in the river channel during the day, but aligned with the current at night. Therefore, the particles traveled fastest when aligned with the strong currents in the river. In contrast, at sites reached by more complex pathways, in Upper Klamath (OSU U8) and Agency Lakes (USGS 25978 and USGS 25979), the maximum difference in the travel times simulated by the four scenarios was 3.9-7.4 d.

The fastest travel to the south (OSU U4) was simulated by scenario $\mathrm{D}$ (table 1 ), in which the movement of particles down the river channel was expedited by alignment with the currents at night, particularly the stronger currents associated with higher streamflow during the first pulse of larvae. Consequently, larvae exited the lake relatively faster, beginning on May 28, in scenario D than in the other scenarios, and fewer total particles were in the domain after that date, although the differences were small (fig. 5A). The lowest retention through both larval pulses, based on $R_{E / A}$, was obtained with passive dispersal (scenario A), and highest retention was obtained with active dispersal by random swimming during the entire diel cycle (scenario B, table 1).

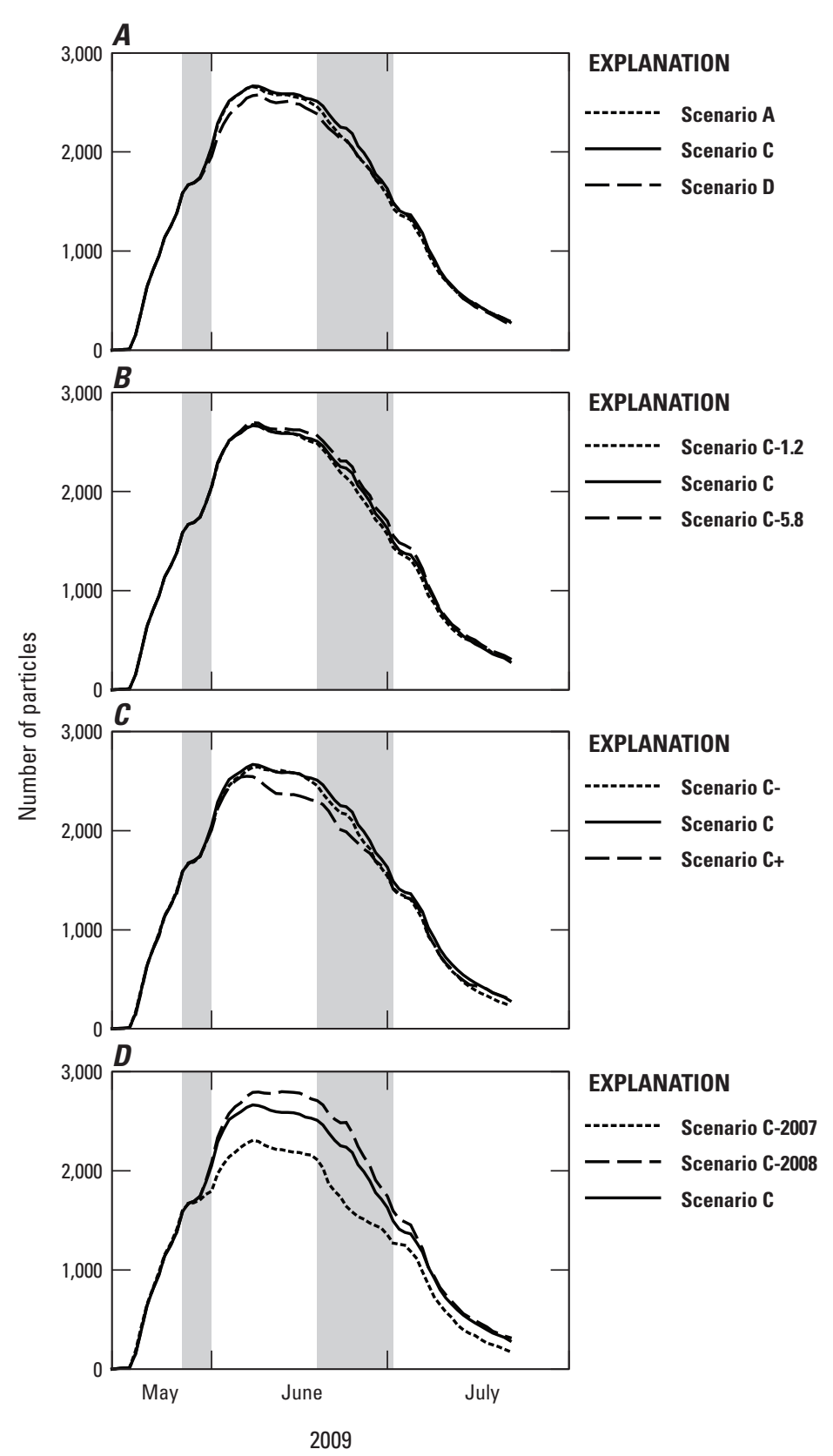

Figure 5. Number of particles remaining in the particletracking simulation as a function of time, after applying a 5 percent per day mortality rate, comparing $(A)$ dispersal scenarios (scenario $B$ is indistinguishable from scenario $C$ and is not shown); $(B)$ swim speeds; $(C)$ lake elevations; and (D) shoreline configurations, Upper Klamath Lake, Oregon, May-July 2009. 


\section{Comparison of Travel Times by Swim Speed}

Random swim speeds also influenced travel times and retention. Differences in simulated travel times between random swimming at speeds of $1.2-5.8 \mathrm{BL} / \mathrm{s}$ were small $(\leq 0.8 \mathrm{~d}$ ) at sites near the river channel and in the delta, and ranged from 0.6 to $4.8 \mathrm{~d}$ at sites from the river mouth to the north and south along the Upper Klamath Lake shoreline (table 1, scenarios C-1.2 and C-5.8). Stronger swimming led to more dispersal, both into the northern delta and Agency Lake and away from the eastern shoreline of Upper Klamath Lake, and weaker swimming led to less dispersal. These differences in dispersal were most evident in the second pulse of larvae when there was weaker advection by currents. When these particles began to exit the lake at Link River on June 19, those swimming at $5.8 \mathrm{BL} / \mathrm{s}$ were more dispersed and therefore, less likely to leave the lake with the eastern boundary current; consequently, there were more particles in the simulation than when swimming was slower, although the differences were small (fig. 5B). Particles swimming randomly at $1.2 \mathrm{BL} / \mathrm{s}$ were less dispersed and more likely to leave the lake with the eastern boundary current, and there were fewer particles in the simulation than when swimming was faster, although the differences were small (fig. 5B). The cumulative retention as measured by $R_{E / A}$ increased with swim speed and was $1.51,1.38$, and 1.11 for swimming at $1.2,3.5$, and $5.8 \mathrm{BL} / \mathrm{s}$, respectively (table 1).

\section{Comparison of Travel Times by Lake Elevation}

Lake elevation influenced particle pathways through the delta (fig. 6; appendix A, simulations at three starting elevations). An elevation near full pool resulted in the most particles leaving the Williamson River channel on the southern delta side, many of them soon after entering the delta. These particles entered Upper Klamath Lake southeast of the Williamson River mouth. As a result, few particles were simulated in the northern delta, at sites in Agency Lake, and along the Upper Klamath Lake shoreline northwest of or at the Williamson River mouth (fig. $6 \mathrm{C}$ and table 1 , scenario C+). Compared to the 2009 observed lake elevation (scenario C), the large number of particles moving quickly through the southern delta in scenario $\mathrm{C}+$ decreased travel time to site OSU U5, on the Upper Klamath Lake shoreline southeast of the river mouth (fig. 1), by $2.3 \mathrm{~d}$, whereas the travel time to site USGS 25976, northwest of the river mouth (fig. 1), increased by $5.8 \mathrm{~d}$. A lake elevation $0.25 \mathrm{~m}$ lower than the observed elevation (scenario C-) resulted in more particles staying in the Williamson River channel and exiting the channel to the north, and fewer passing through the southern delta to enter Upper Klamath Lake southeast of the river mouth (fig. 6A). This happened because the connection between the Williamson River channel and the southern delta was restricted at the lower lake elevation, particularly near the entrance to the delta. As a result, travel times to sites at the river mouth and along the Upper Klamath Lake shoreline northwest of the mouth were faster than simulated at the 2009 observed lake elevation (table 1), and fewer particles were retained in the simulation (fig. 5C), reflecting the faster transport into Upper Klamath Lake. Compared to the observed lake elevation, at the lower elevation more particles were captured offshore of the river mouth and at the shoreline sites northwest of the river mouth (table 1). The overall cumulative retention as measured by $R_{E / A}$ was greatest at the observed lake elevation (1.38), and less for elevations both lower (1.43) and higher (1.53) (table 1).

\section{Comparison of Travel Times by Shoreline Configuration}

Changes in the shoreline configuration associated with restoration of the delta between 2007 and 2009 dramatically altered how particles entered and traveled through the delta and Upper Klamath Lake (appendix A, simulations at three shoreline configurations). When the 2007 shoreline was used, particles entered the lake at the mouth of the river as a densely packed kernel. When the northern delta was reconnected, particles left the channel at several points along the northern side, and many took longer and more complicated pathways to Upper Klamath Lake, entering at breaks in the levees northwest of the mouth or from Agency Lake. This resulted in more particles captured at sites along the shoreline northwest of the mouth, and fewer particles at the river mouth, as well as travel times that were consistently longer than before the northern delta was reconnected, as particles took longer routes to Upper Klamath Lake (table 1). These longer routes resulted in more particles retained during much of the simulation (fig. $5 \mathrm{D}$ ). When both sides of the delta were reconnected, particles could leave the river channel along both sides. Advection under prevailing wind conditions resulted in more particles moving through the southern delta than the northern delta, so travel times to sites southeast of the river mouth decreased between 2008 and 2009 (table 1) as did the number of particles in the simulation (fig. 5D). The overall cumulative retention as measured by $\mathrm{R}_{\mathrm{E} / \mathrm{A}}$ was lowest for the pre-restoration shoreline configuration (1.75), increased with the first phase of restoration (0.98), and decreased after the second phase of restoration (1.38) (table 1). 


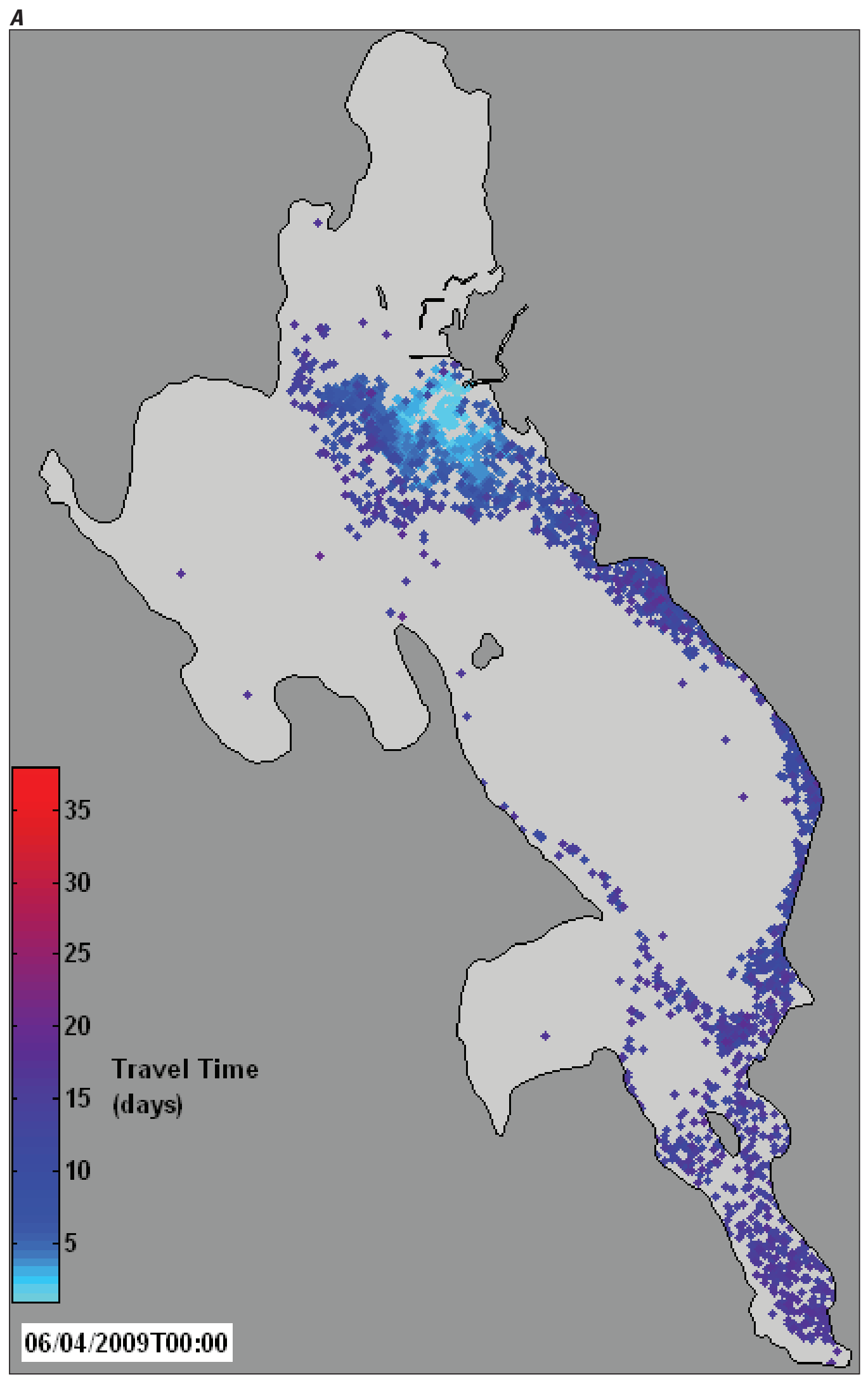

Figure 6. Screen captures showing particle simulations of swimming scenario $\mathrm{A}$ at midnight on June 4, 2009, for three elevation scenarios in Upper Klamath Lake, Oregon. (A) Elevation at 0.25 meter below measured elevation; $(B)$ elevation as measured; and $(C)$ elevation at 0.19 meter above measured elevation. 


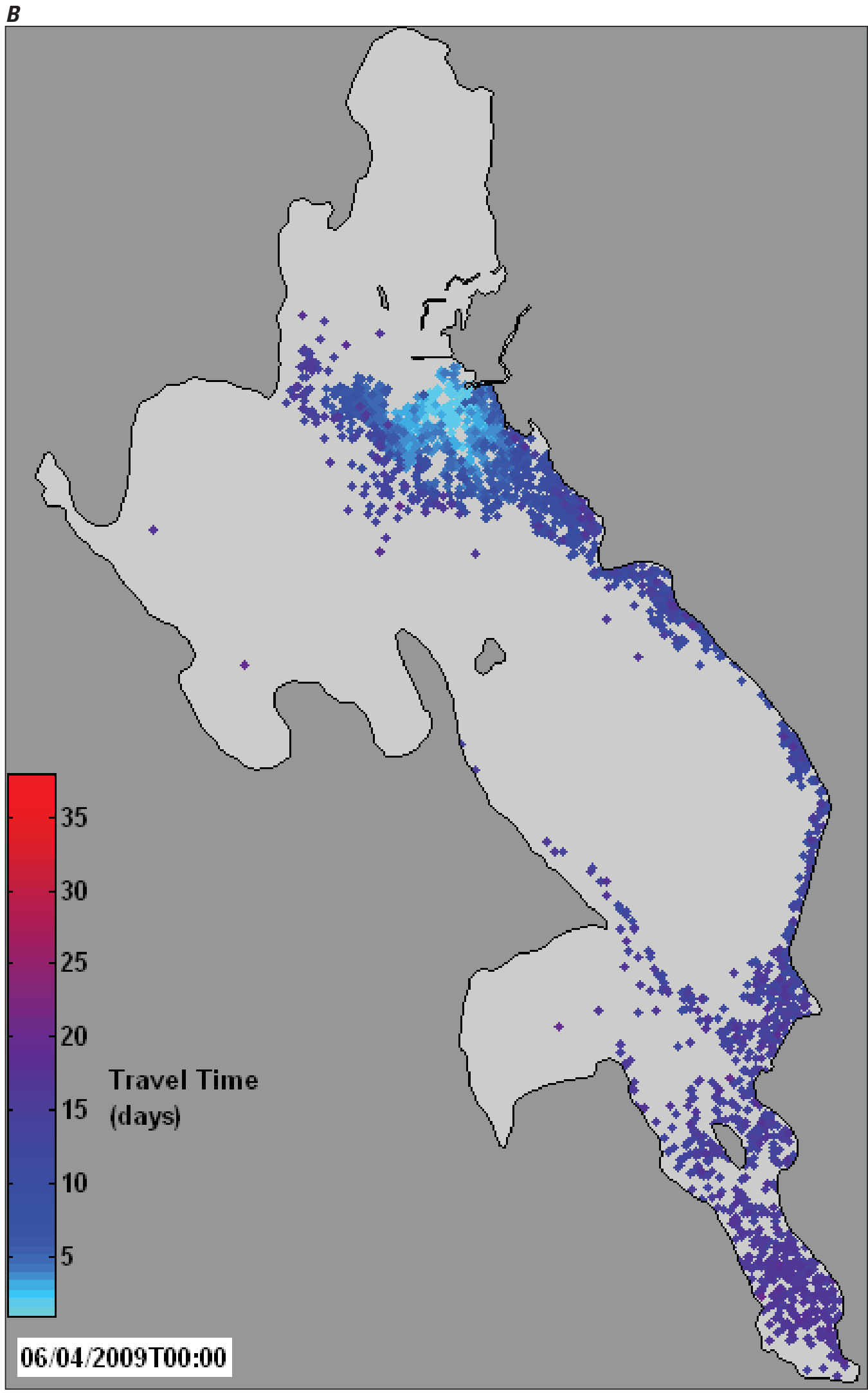

Figure 6.-Continued 


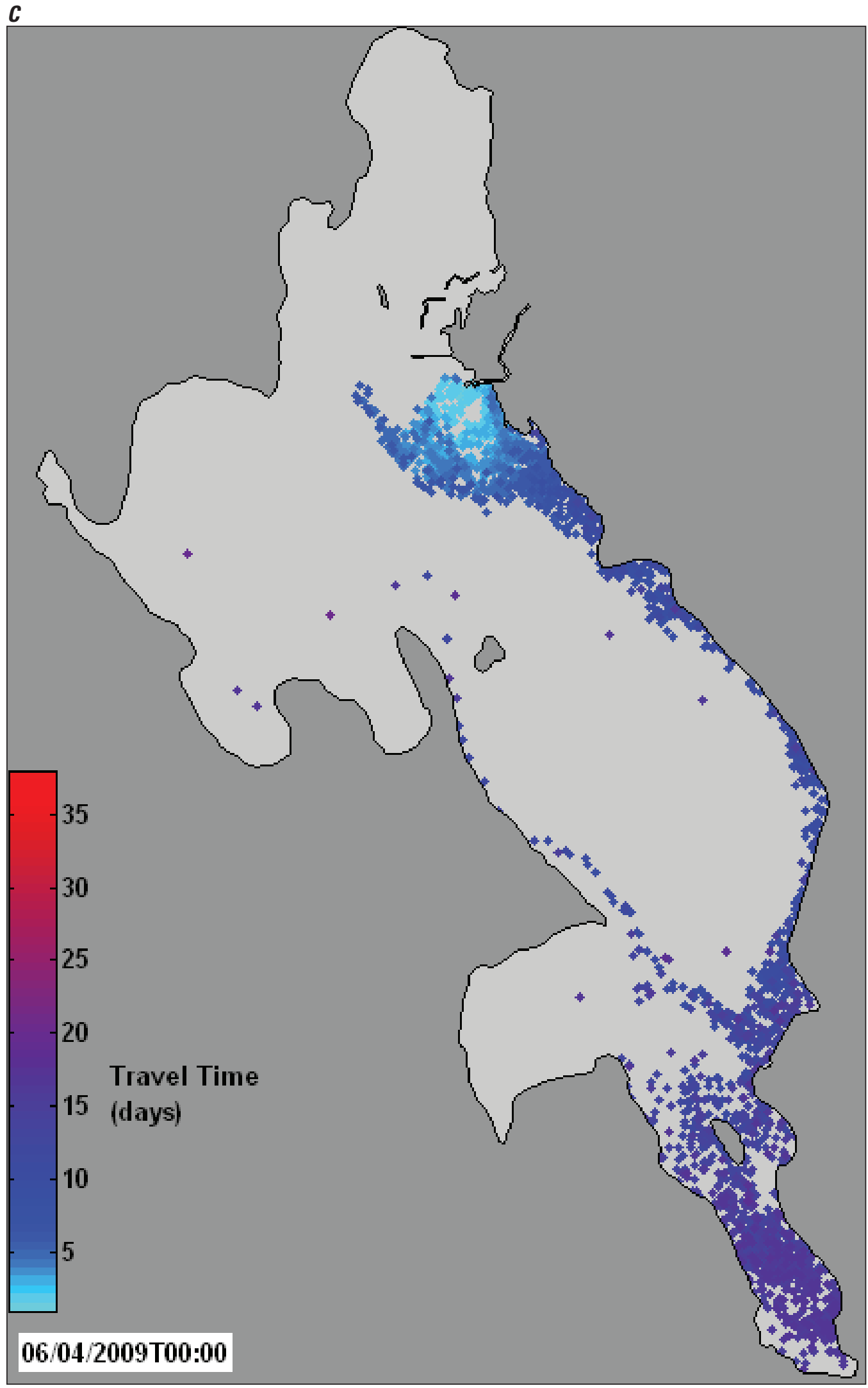

Figure 6.-Continued 


\section{Field Data}

Excluding the boundary site at Modoc Point Road, 24,232 individuals of several species were captured in 2009 (table 2). Collectively, suckers constituted only 6.36 percent of the catch and their proportion declined with distance from the river channel, being 10.6 percent of the TNC samples, 5.5 percent of the USGS samples, and 3.1 percent of the OSU samples.

When the number of suckers caught at fixed sites was greater than 10 , there was not an obvious progression in length from shorter to longer with distance from the upstream boundary (table 3). Different gears fished at sites near each other sometimes were similar in median larval sucker lengths (OSU U6 and USGS 25981 differed by $<0.1 \mathrm{~mm}$ ), but also could differ substantially (TNC B and USGS 25535 differed by $2.0 \mathrm{~mm}$ ). A comparison of the range in the size of fish caught at pop net site TNC B $(12-17 \mathrm{~mm}$, fig. 7) to the range in size of fish caught at plankton net site USGS 25535 (10-14 mm, fig. 8), located near each other, suggests differences in gear efficiencies or sampling protocols, such that pop nets catch fewer fish shorter than $12 \mathrm{~mm}$, and plankton nets catch fewer fish longer than $14 \mathrm{~mm}$. Similarly, the range in size at USGS 25981 (12-14 mm), located offshore from larval trawl site OSU U6, where the range in size was 10-20 mm (fig. 9), further suggests that plankton nets catch fewer relatively "large" fish than pop nets.

Table 2. Summary of larval fish catches by family, species, and collecting agency from selected sites in Upper Klamath Lake and the Williamson River Delta, Oregon, 2009.

[Agency: TNC, The Nature Conservancy; USGS, U.S. Geological Survey, OSU: Oregon Sate University. -, none caught]

\begin{tabular}{|c|c|c|c|c|c|c|}
\hline \multirow{2}{*}{ Family } & \multirow{2}{*}{ Species } & \multicolumn{3}{|c|}{ Agency } & \multirow{2}{*}{ Total } & \multirow{2}{*}{ Percent } \\
\hline & & TNC & USGS & OSU & & \\
\hline \multirow[t]{4}{*}{ Catostomidae } & & 963 & 249 & 328 & 1,540 & 6.36 \\
\hline & Lost River sucker & 75 & 74 & 47 & 196 & 0.81 \\
\hline & Shortnose/Klamath largescale sucker & 630 & 168 & 222 & 1,020 & 4.21 \\
\hline & Unidentified sucker & 258 & 7 & 59 & 324 & 1.34 \\
\hline \multirow[t]{6}{*}{ Cyprinidae } & & 8,135 & 4,195 & 10,179 & 22,509 & 92.89 \\
\hline & Tui chub & 1,007 & 1,489 & 215 & 2,711 & 11.19 \\
\hline & Blue chub & 2,757 & 805 & 5,450 & 9,012 & 37.19 \\
\hline & Fathead minnow & 4,371 & 1,901 & 4,448 & 10,720 & 44.24 \\
\hline & Speckled dace & - & - & 2 & 2 & 0.01 \\
\hline & Unidentified minnow & - & - & 64 & 64 & 0.26 \\
\hline \multirow[t]{4}{*}{ Cottidae } & & 3 & 1 & 43 & 47 & 0.19 \\
\hline & Marbled sculpin & - & - & 40 & 40 & 0.17 \\
\hline & Slender sculpin & - & - & 3 & 3 & 0.01 \\
\hline & Unidentified sculpin & 3 & 1 & - & 4 & 0.02 \\
\hline \multirow[t]{2}{*}{ Percidae } & & 10 & 58 & 41 & 109 & 0.45 \\
\hline & Yellow perch & 10 & 58 & 41 & 109 & 0.45 \\
\hline \multirow[t]{3}{*}{ Centrarchidae } & & - & - & 3 & 3 & 0.01 \\
\hline & Largemouth bass & - & - & 1 & 1 & 0.00 \\
\hline & Unidentified sunfish & - & - & 2 & 2 & 0.01 \\
\hline Unidentified & & - & 24 & - & 24 & 0.10 \\
\hline Grand totals & & 9,111 & 4,527 & 10,594 & 24,232 & \\
\hline
\end{tabular}




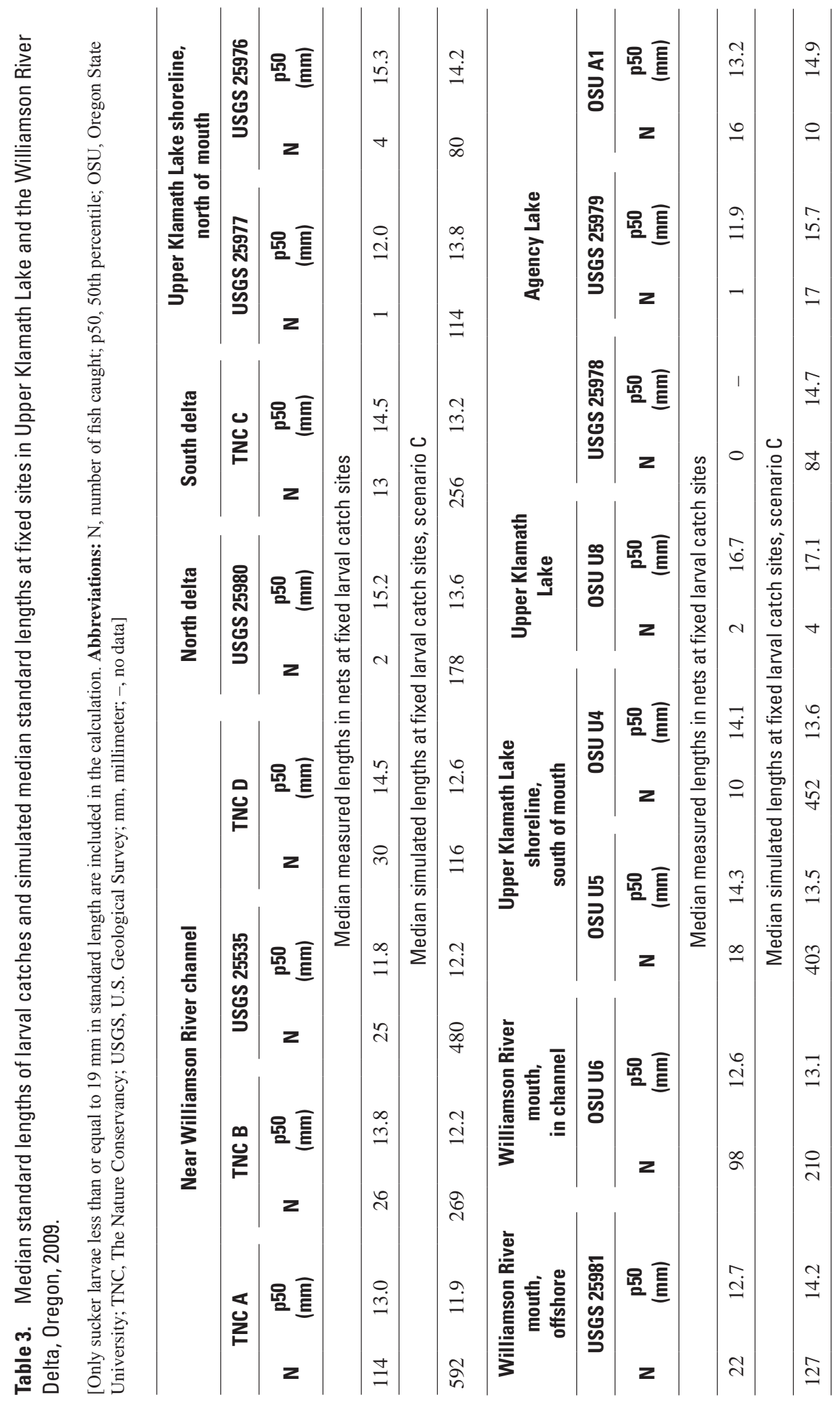




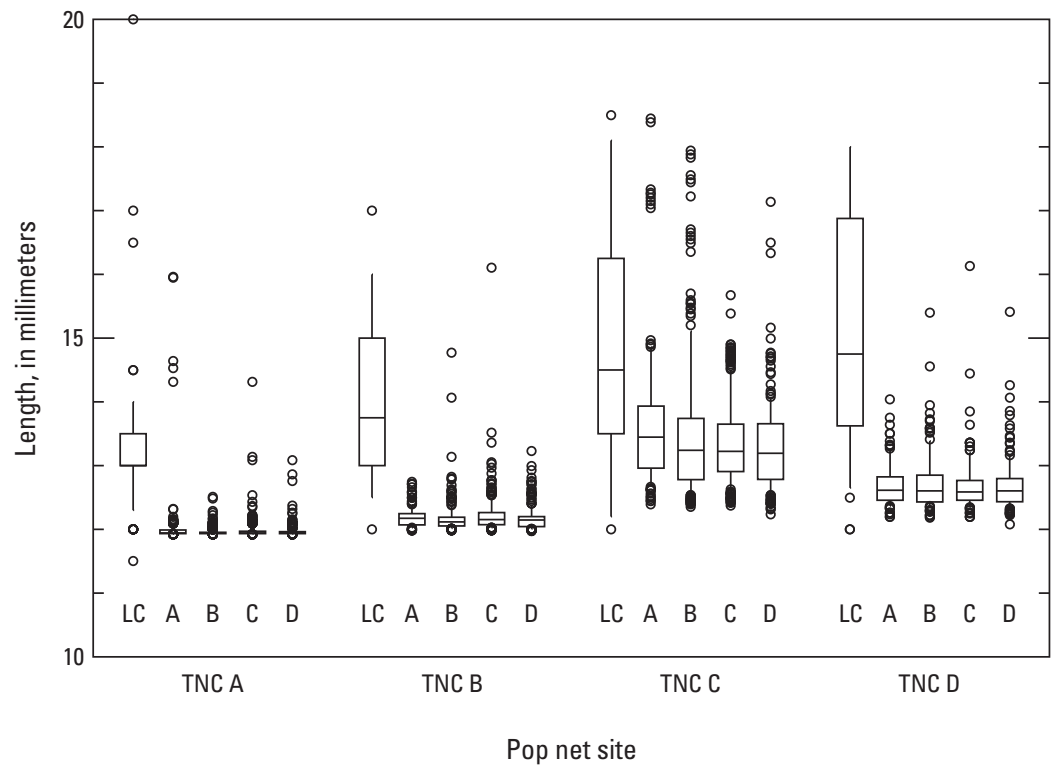

\section{EXPLANATION}

- Outlier

90th percentile

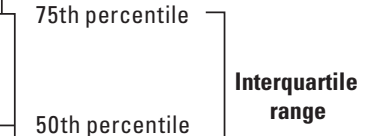
(median)

25th percentile -

10th percentile

Outlier

LC Larval catch data

A Dispersal scenarios A-D, respectively

Figure 7. Length distribution of larval suckers in nets and of simulated particles at pop net sites in Upper Klamath Lake, Oregon, May-July 2009.

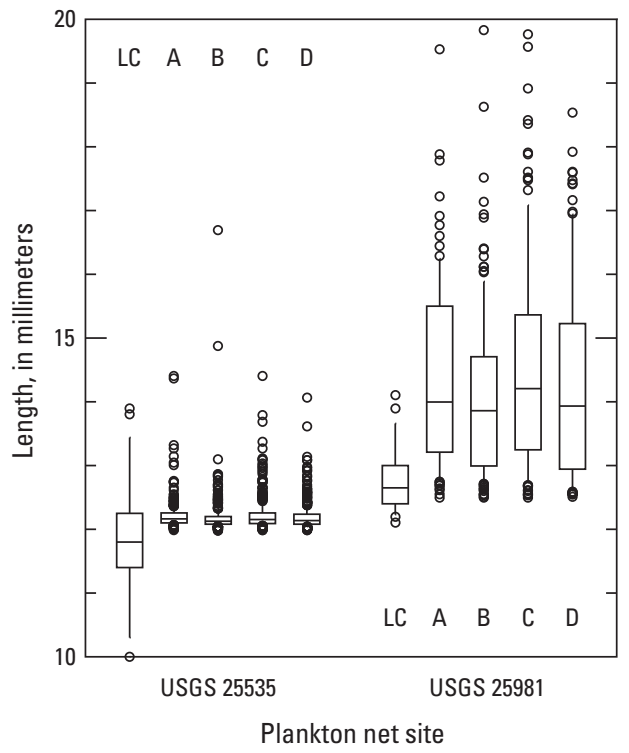

EXPLANATION

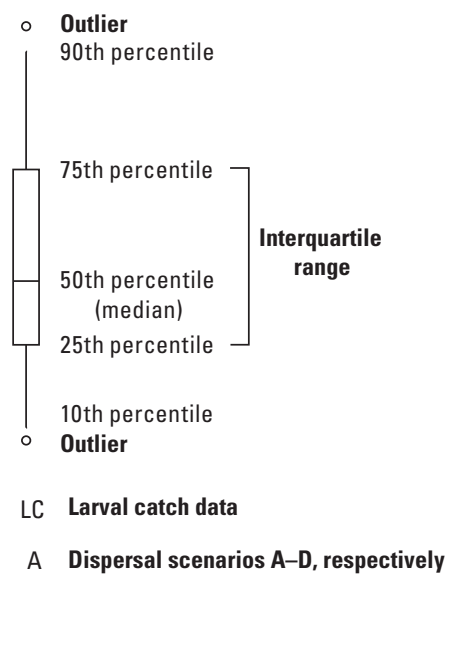

Figure 8. Length distribution of larval suckers in nets and of simulated particles at plankton net sites in Upper Klamath Lake, Oregon, May-July 2009. 

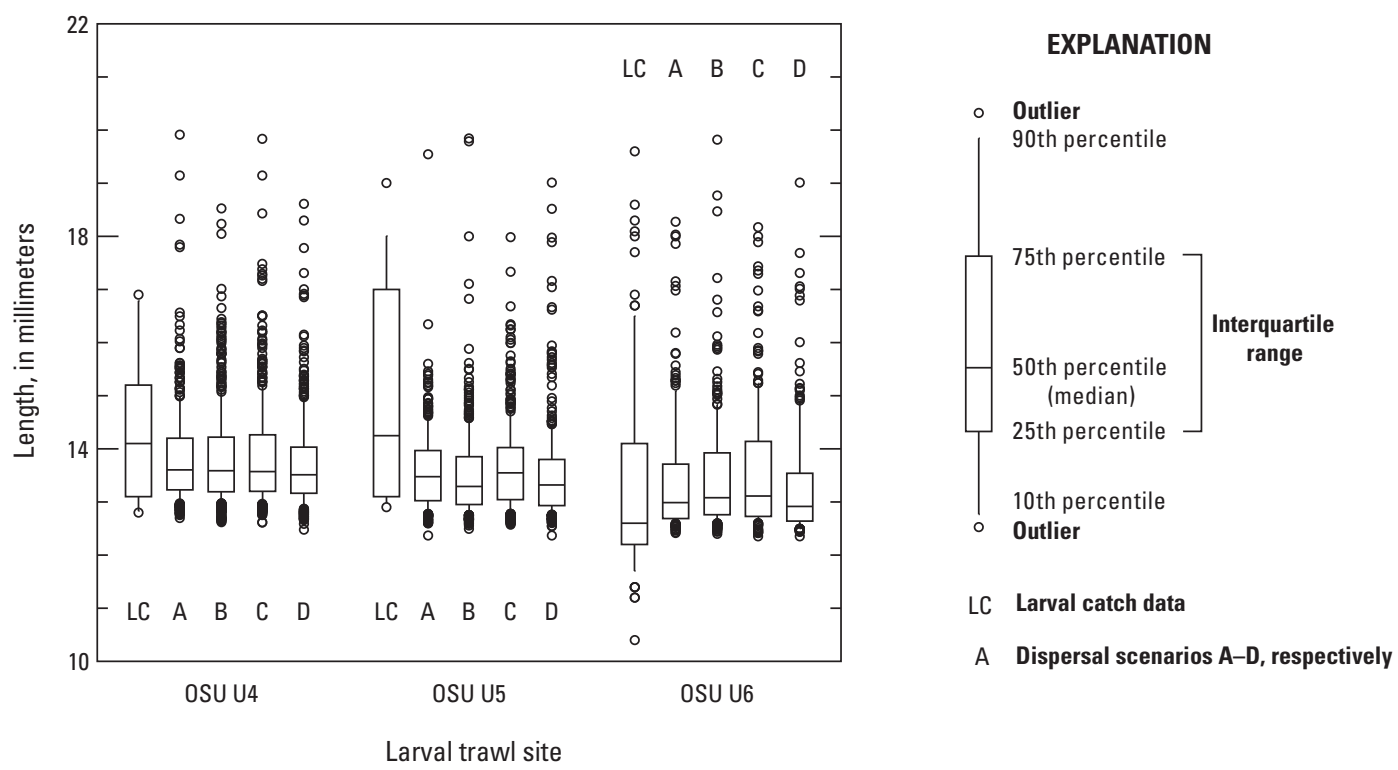

Figure 9. Length distribution of larval suckers in nets and of simulated particles at larval trawl sites in Upper Klamath Lake, Oregon, May-July 2009.

\section{Model Validation}

At pop net fixed sites, larvae were longer than would be expected from ages of simulated particles on the basis of the length-at-age relation by 1.1-2.2 $\mathrm{mm}$ (table 3 , fig. 7). At the 2 plankton net fixed sites where at least 10 fish were caught, the larvae were shorter than simulated particles by 0.4 to $1.6 \mathrm{~mm}$ (table 3 , fig. 8). At larval trawl fixed sites where at least 10 fish were caught, larvae were longer than simulated particles by as much as $0.8 \mathrm{~mm}$ or shorter than simulated particles by as much as $0.5 \mathrm{~mm}$ (table 3 , fig. 9). At individual sites without regard to gear type, median lengths were up to $2.2 \mathrm{~mm}$ longer than simulations (fig. 7, TNC D), essentially comparable to simulations (fig. 9, OSU U6), or shorter than simulations by as much as $1.6 \mathrm{~mm}$ (fig. 8, USGS 25981).

Given that gear efficiencies likely differ, simulated lengths are most appropriately compared to lengths in net catches among the same gear types, rather than across gear types. The simulated and measured differences in median length between a given pair of sites of the same gear type were usually of the same sign but differed in magnitude. At pop net sites, simulated and measured differences in median lengths between TNC A and TNC B were 0.3 and $0.8 \mathrm{~mm}$, respectively; between TNC A and TNC C were 1.3 and $1.5 \mathrm{~mm}$, respectively; and between TNC A and TNC D were 0.7 and $1.8 \mathrm{~mm}$, respectively (ig. 7; table 3 ).
At plankton net sites, simulated and measured differences in median lengths between USGS 25535 near the channel and USGS 25981 offshore from the Williamson River mouth were 2.0 and $0.9 \mathrm{~mm}$, respectively (fig. 8, table 3 ). At larval trawl sites, simulated and measured differences in median lengths between OSU U6 and OSU U5 were 0.4 and $1.7 \mathrm{~mm}$, respectively; between OSU U6 and OSU U4 were 0.5 and $1.5 \mathrm{~mm}$, respectively; and between OSU U5 and OSU U4 were 0.1 and $-0.2 \mathrm{~mm}$, respectively (fig. 9 , table 3 ).

The dispersal scenario that best matched larval lengths depended on how the data were parsed. When all data were combined, the correlation between simulated and measured lengths was highest for passive dispersal $(\mathrm{R}=0.46$, scenario $\mathrm{A}$, table 4). When correlations were made by gear type, plankton and pop net data correlated most highly with passive dispersal (scenario A) ( $\mathrm{R}=0.76$ and 0.36, respectively), but larval trawl data correlated most highly with active dispersal by random swimming (scenario $\mathrm{B})(\mathrm{R}=0.49)$. Scenario $\mathrm{C}$ (active dispersal by random swimming with nighttime-only drift in the Williamson River) resulted in the least overall bias ( -0.3 , -1.3 , and $0.0 \mathrm{~mm}$ for larval trawl, pop net, and plankton net data, respectively). Across all dispersal scenarios, correlations with plankton net data spanned the highest range from $\mathrm{R}=0.30$ to $\mathrm{R}=0.76$, and the bias between the simulated and measured lengths was smaller than in the combined dataset, ranging from $+0.1 \mathrm{~mm}$ to $-0.3 \mathrm{~mm}$. 


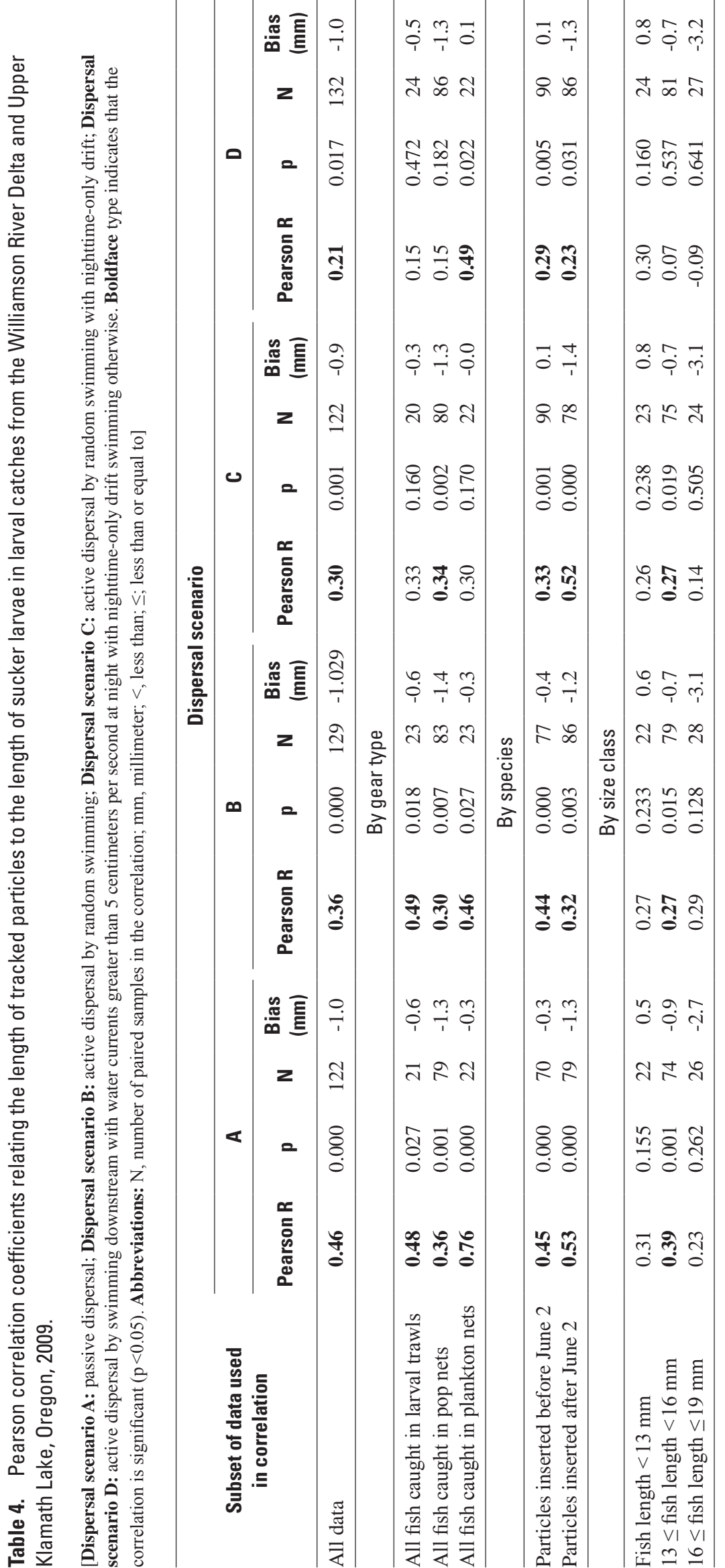


When the data were analyzed separately for particles inserted into the domain before and after June 2, the correlation was significant across all dispersal scenarios for particles inserted after June 2 ( $R$ between 0.23 for scenario $D$ and 0.53 for scenario A), when drift was dominated by shortnose suckers and advection by currents was relatively weaker (table 4). Correlation was lower across all dispersal scenarios for those particles inserted prior to June 2, when drift was dominated by Lost River suckers and advection by currents was relatively stronger (highest $\mathrm{R}=0.45$ for scenario A). When correlations were made by size class, consistently positive correlations ( $\mathrm{R}$ between 0.26 and 0.31 ) resulted across all dispersal scenarios for the smallest-size class (fish length $<13 \mathrm{~mm}$ ). Significant correlations resulted for the middle-size class (fish length $\geq 13$ and $<16 \mathrm{~mm}$ ) across three of the four dispersal scenarios (highest $R=0.39$, scenario A). The lowest correlations were in the largest-size class (fish length $\geq 16$ and $\leq 19 \mathrm{~mm}$ ).

\section{Discussion}

Currents through the delta are primarily wind driven. Winds typically exhibit an approximately diel pattern: light during morning and early afternoon and stronger during the evening and night. During periods of low wind speed, currents are slow across the delta and fastest in the river channel. When wind speeds are high, currents are slower in the northern delta than in the shallower southern delta. West-to-northwest winds generally cause water to enter the northern part of the delta from breaches in the levees along the Agency Lake side and to flow into Upper Klamath Lake through breaches in the levees on the Upper Klamath Lake side, or to flow across the river channel into the southern part of the delta (fig. 4A). In the shallow southern delta, strong currents enter at river breaches and take a nearly direct route south to exit through breaches in the levees on the Upper Klamath Lake side of the delta (figs. 2 and $\underline{4 A}$; see also Wood, 2012). Our simulations were consistent with the overall understanding of how water moves through the delta, in that they showed that particle trajectories through the delta were affected by wind speed and direction, lake elevation, and shoreline configuration.

Outside the delta, the large-scale pattern of wind-driven circulation transports particles south along the eastern shoreline of the lake. The eastern shoreline transport is part of a lakewide clockwise circulation in which water moves southeastward in a broad, shallow flow along the eastern side of the lake and returns in a narrow, deep, northwestward flow through the trench along the western shore (fig 1; see also Wood and others [2008]). Some of the southeastward flow continues to the south of Buck Island, and from there water can be recirculated to the north of Buck Island and back into the clockwise circulation, or it can exit the lake through the
Link River outlet. Our simulations showed that after leaving the delta, particle travel time and retention were affected by wind speed and direction, and lake elevation, as well as simulated behavior.

In the delta, particle travel times were fast and particle pathways were direct across the southern delta, the Williamson River channel, and southeast along the shoreline of Upper Klamath Lake, whereas particle travel times were longer and pathways were more complex in the northern delta and Upper Klamath Lake and Agency Lake northwest of the river mouth (table 1). Strong west-northwest winds and higher lake elevation resulted in faster travel times of particles across the southern delta and into the lake. Weaker winds with more variable directions and lower lake elevation resulted in slower travel times, more complex pathways through the northern delta, and more variable points of entry into the lake. Different assumptions regarding dispersal (compare scenarios $\mathrm{A}-\mathrm{D}$ in table 1) and swim speed (compare scenarios C-1.2, C and C-5.8 in table 1) resulted in differences of much less than $1 \mathrm{~d}$ in travel times to sites near the river channel and as much as $1.5 \mathrm{~d}$ to sites farther from the river channel and at the river mouth. Therefore, differences in travel time resulting from these various assumptions increased with distance from the upstream boundary, but were always small. Within the lake, swimming oriented to current direction resulted in faster downstream travel, a quicker exit of particles from the lake, and fewer particles in the domain than random swimming. When swimming was random, stronger swimming led to more dispersal, fewer particles leaving the lake, and more particles in the domain than with slower random swimming. Transport out of the lake, therefore, was determined by the speed of the eastern boundary current, which is a function of wind speed and lake elevation, and whether behavior enhanced that transport (aligning with currents) or countered that transport through greater dispersal (faster random swimming). The sensitivity of particle travel time and retention to different dispersal assumptions was small, however, in comparison to the sensitivity of these quantities to lake elevation and shoreline changes.

When the lake elevation was near full pool, prevailing wind-driven currents moved most particles directly and quickly, southeastward across the southern delta and into the lake, with few particles traversing the northern delta (fig. 6C). Relative to the 2009 elevation, particle travel times were shorter by as much as $2.6 \mathrm{~d}$ to sites southeast of the river mouth, but were longer by as much as $11.5 \mathrm{~d}$ to sites northwest of the river mouth (table 1 , scenario $\mathrm{C}+$ ). When the lake elevation was $0.25 \mathrm{~m}$ below the 2009 measured elevation (fig. 6A), fewer particles passed through the southern delta and more particles stayed in the river channel or traversed the northern delta. Relative to the 2009 elevation, particle travel times to most sites along the Upper Klamath Lake shoreline north, south, and offshore of the river mouth were faster, by as much as $4.6 \mathrm{~d}$ (table 1 , scenario C-). When compared to the 
simulation at full pool, the simulations at the 2009 elevation and at a lower elevation showed that lake elevations lower than full pool retained more particles in the lake. There was evidence, however, that an intermediate "optimal" lake level that partially restricted transport into the southern delta, particularly close to the delta entrance, while still allowing the particles access to both the northern and southern sides of the delta farther downstream, would retain the most particles and result in the slowest travel times to the lake.

Simulations with shorelines representing the changes in the delta between 2007 and 2009 provided insight into the changes in larval transport attributed to restoration (scenarios C-2007, C-2008, and C in table 1). Prior to restoration, the route to Upper Klamath Lake for all particles was fast and direct through the Williamson River channel. The reconnection of the northern delta in 2008 allowed particles to take long and complicated pathways into Upper Klamath Lake, effectively increasing travel time to all "downstream" sites in the lake, and increasing retention in the lake relative to the 2007 shoreline. When both sides of the delta were reconnected, prevailing winds created strong currents through the shallow southern delta, and more particles took a direct route through the southern delta to Upper Klamath Lake, so travel times to sites southeast of the river mouth decreased between 2008 and 2009, as did the retention of particles. However, both the 2008 and 2009 shorelines slowed the transport of particles and increased retention relative to pre-restoration conditions.

When particle ages were converted to lengths, field data agreed modestly with simulations though larvae usually were longer than predicted from particle ages, particularly for the largest size class (lengths $\geq 16 \mathrm{~mm}$ and $\leq 19 \mathrm{~mm}$ ) (table 3). Correlations with field data among all gear types, species (as determined by date of entry into the lake), and size classes were consistently positive for three of our dispersal scenarios (all but oriented swimming) and provided an additional, moderate level of corroboration for four model (table 4). Overall, the highest correlations with field data were obtained with the assumption of passive dispersal (Pearson $\mathrm{R}$ between 0.23 and 0.76 , depending on how data were parsed), but the assumption of active dispersal throughout the day also resulted in moderate R values (0.27-0.49) and slightly less bias in the simulated lengths of fish. There was no compelling evidence, however, that any scenarios for active dispersal through swimming resulted in a better or worse description of larval dispersal than the assumption of passive dispersal. The correlation with field data was higher for those particles inserted after June 2 than for those inserted before June 2. Lost River sucker larvae usually enter the delta 2-4 weeks before shortnose sucker larvae, and June 2 provided an approximate demarcation date between entry of the two species, based on our 2009 boundary samples. This suggests that the particle simulation was better at describing dispersal of shortnose sucker larvae, that the field sampling was worse at measuring Lost River sucker larvae in the system, or both.
Most biophysical models have disconnects with field data (Leis, 2007), and this model was no exception. The extent to which these disconnects are a result of model assumptions or the inability of the empirical data to describe conditions in the environment with sufficient accuracy is unknown. For example, the simulated lengths generally were smaller than the measured lengths of fish captured in nets. This bias was not uniform across gear types, however, and was greatest for pop net catches, less for larval trawl catches, and smallest for plankton net catches.

Intra- and inter-gear differences in efficiencies are seldom mentioned in larval dispersal modeling (Leis, 2007); most researchers simply acknowledge that different gears deployed in different ways in the same place sometimes give different results (Overton and Rulifson, 2007). For this study, all nets were assumed maximally efficient for the smallest larvae and analyses were restricted to larvae less than $19 \mathrm{~mm}$, but there were obvious spatial and gear differences. Small larvae (10-13 mm) constituted 87 percent of all larvae at plankton net sites, 36.2 percent at pop net sites, and 34.1 percent at larval trawl sites. However, at the larval trawl site closest to the larval source at the mouth of the Williamson River (OSU U6), the small size class constituted 59.4 percent of the catch and was more similar to plankton net samples. Therefore, the gear-specific differences may be attributed partly to site location as well, such that sites closest to the river source, where pop and plankton nets were the predominant types used, had the smallest larvae. A better understanding of the size efficiency of nets (Millar and Fryer, 1999) is needed to distinguish between spatial and gear-specific differences in the size of the catches. The gear-specific differences also are due to sampling different parts of the water column, where ontogenetic shifts in larval sucker behavior could also account for some of the variation. For example, a diet study of sucker larvae and juveniles from Upper Klamath Lake suggested that the approximate 50 percent surface-50 percent benthic diet transition occurs at a standard length of about $20 \mathrm{~mm}$. However, individuals vary greatly and benthic foods can constitute 25 percent or more of the diet in a 15-mm, standard-length larva (Markle and Clauson, 2006), which indicates that a gradual and variable vertical transition in orientation is a likely cause for some of the observed differences in catches. In addition, our catches were made during the day, and the occupation of different parts of the water column by larval suckers for feeding or other reasons could have a diel dependence.

Our focus on an endangered species present in low densities adds an additional problem not found in typical studies that focus on the most abundant species. Density simulations (Wood and others, 2012) showed that larvae at our initial concentrations of between 20 and $50 \mathrm{fish} / \mathrm{m}^{3}$ at the Modoc Point Road Bridge would have concentrations less than $1 \mathrm{fish} / \mathrm{m}^{3}$ when dispersed passively to sites more than a few kilometers away from the Williamson River channel. If 
fish are uniformly distributed, these densities are close to a density detection limit for the gear types used. For example, at one larva per net, the larval trawl detection limit was between 0.14 and $2 \mathrm{fish} / \mathrm{m}^{3}$, the pop net detection limit was between 0.37 and $3.0 \mathrm{fish} / \mathrm{m}^{3}$, and the plankton net detection limit was between 0.012 and $3.7 \mathrm{fish} / \mathrm{m}^{3}$. Given the low simulated densities in areas far from the Williamson River channel, many zero catches in the field samples should be expected, particularly because larval fish are not expected to be uniformly distributed within a 75-m radius around a sample site, but instead are expected to be clustered. Therefore, the rarity of the target species may have further added imprecision to the larval catch densities and the length distributions obtained from those catches.

Many simplifying assumptions were made in the model. With regard to swimming, larvae were assumed to be passive, to have active random swimming behavior, or to have active swimming with simple current orientation behavior, and had simple day-night drift behavior that was constrained to occur everywhere within the Williamson River channel but nowhere outside the channel. Descriptions of swimming behavior were based on descriptions of the behavior of similar elongate larvae in the literature, and were designed primarily to test the sensitivity of the dispersal patterns to some swimming behaviors. Most routine measures of swimming performance, critical speed and burst speed, are not suitable for use in models of larval dispersal (Irisson and others, 2009), for which a routine, sustainable speed is required. Cues that trigger changes in swimming are unknown, whereas the suite of potential cues (age, size, temperature, or detection of shorelines, currents, or chemicals [Trnski, 2002; Leis and Carson-Ewart, 2003]) is large.

The better performance of the model in simulating particles during the period when shortnose sucker larvae rather than Lost River larvae should have been most abundant may be due to behaviors not included in the model. For example, some evidence shows that Lost River sucker early juveniles are found preferentially in open water, whereas shortnose sucker juveniles are found closer to the shoreline (Simon and others, 2009). Most of our field samples were collected close to shore, close to the delta, or in the transit path that any larva would need to travel from the river to the lake, rather than in open water. In 2009, even though the density of Lost River suckers in the drift in the Williamson River was greater than that of shortnose suckers (Wilcoxon test, $p<0.05$ ), Lost River suckers were five times less likely to be in our nets ( 0.81 percent of our samples compared to 4.21 percent for shortnose suckers; table 2), suggesting that the field samples might be biased in favor of the collection of shortnose suckers. Markle and others (2009) found that Lost River sucker larvae, aged 17-42 days, dispersed more quickly out of the lake and speculated that they were more dependent on gyre retention than shoreline retention. The present analysis included only one site (OSU U8) that appeared to be influenced by gyre retention, so this hypothesis remains largely untested.
Other simplifying assumptions in the model regarded entry age and mortality. The age of larvae at the upstream boundary was a single age rather than a true age distribution, and age and size relations were assumed to be linear across the larval size range, with no seasonal adjustments. Mortality was modeled as spatially uniform and independent of age, a common compromise (Helbig and Pepin, 1998). Of these assumptions, the assumption of spatially uniform, ageindependent mortality was the most critical because of its effect on the model and its biological improbability. Mortality is an important variable to include in biophysical models (Hare and others, 2002), but details are needed in addition to the crude estimates generally available. One potential driver of spatial patterns that is not investigated in biophysical models is that aggregations of larvae could be a result of spatially non-uniform mortality. Estimating site-specific mortality requires determination of the confounding effects of migrations (Helbig and Pepin, 1998). In one attempt, Markle and others (2009) found as much as an order of magnitude difference in apparent mortality for different ages of sucker larvae and different sites in Upper Klamath Lake. The success of our correlation analysis suggests that our simulation of the advection and dispersal of larvae can replicate the spatial and temporal variability of fish lengths of the field data, but that simulated lengths were almost uniformly biased low, and adding spatial- and age-dependent mortality to the model could be an important improvement.

This study supports the hypothesis that advection trajectories of larval fish are a product of interactions of ontogeny and behavior with hydrography (Bradbury and others, 2006; Leis and others, 2006). Our simulations identified temporal patterns determined by the timing of larval pulses in the Williamson River and spatial patterns resulting from complex interactions of wind-driven currents with the bathymetry of the delta and remnants of the levees around it.

These simulations were done to help describe the effects of a major delta restoration project on larval dispersal, to help interpret field data, and to evaluate management options for retaining more larvae in the lake. Restoration projects commonly end when on-the-ground work is completed, with no detailed evaluation of the initial assumptions and actual effects of the project. This model is a tool to aid understanding of the effect that restoration of the Williamson River Delta has on the dispersal of larval suckers and the ability of the project to increase retention of larvae in Upper Klamath Lake.

The simulations show that transit through the delta is dependent on wind speed and that strong prevailing winds cause more particles to take a route through the southern delta. The simulations also suggest that lake elevation might be used to optimize the tradeoff between keeping lake elevation low enough to maximize the number of larvae that are transported to the northern delta, which tends to result in slower travel times overall to the lake, but high enough to minimize the number of larvae that are sent down the Williamson River 
channel, which results in faster travel times to the lake. Bathymetry and vegetation are expected to change as the delta matures, and the model can be used to predict the response in travel times to those changes. The model also can be used as a tool to visualize dispersal tracks and to highlight conflicts with field data. Dispersal tracks can be used to establish more efficient sampling protocols by weighting areas based on predicted sizes and abundance. Conflicts with field data can be used to focus on biologically meaningful questions such as species differences, behavioral cues to swimming and settlement, and spatial patterns in mortality. All of these analyses can lead to better hypotheses about the importance of larval dispersal in year class formation.

\section{Summary}

A hydrodynamic model was used to track particles representing individual Lost River and shortnose sucker larvae in Upper Klamath Lake, Oregon. Simulated travel times were used to determine the length of pathways taken by individual particles to sites within the lake, particularly sites on either side of the Williamson River channel in the recently (2007-2008) re-flooded deltaic area surrounding the lowest 5 kilometers of the river, and sites along the eastern shoreline of the lake north and southeast of the pre-2007 river mouth. Travel times generally increased with distance from the Modoc Point Road Bridge (upstream boundary of the simulations), both along the river channel and away from the river channel into the deltaic areas north and south of the channel. Travel times to sites in the northern delta and along the shoreline of Upper Klamath Lake northwest of the mouth of the submerged Williamson River channel generally were slower than travel times to sites at comparable distances from the upstream boundary in the southern delta and along the shoreline of the lake southeast of the submerged channel mouth. This was because the prevailing winds tend to drive water currents to the southeast across the delta, and, therefore, transport to points south is aided directly by currents and is more direct and faster than transport to points north.

Several different scenarios for individual swimming behavior were implemented: completely passive dispersal, random swimming with and without nighttime-only drift in the river channel, and active swimming through alignment with the currents. The fastest travel times were simulated for particles that aligned with the currents, as this expedited transport down the river channel to the lake and across the shallow southern delta to enter the lake southeast of the channel mouth. This behavior also resulted in the fastest exit of particles from the lake and the least retention. This was in contrast with random swimming, which resulted in slower travel times to most sites than swimming aligned with currents. As the strength of random swimming increased, dispersal of particles increased and retention in the lake increased. Overall, however, the sensitivity of particle travel time and retention to different dispersal assumptions was small in comparison to the sensitivity of these quantities to lake elevation and shoreline changes.

Simulations were completed using three shoreline configurations in order to compare the simulated results from 2009 (after restoration of the Williamson River Delta was completed) to simulated results prior to the start of restoration (2007), and partway through restoration when only the northern part of the delta was reconnected to the lake (2008), assuming that all boundary conditions were the same. The purpose of the comparison was to determine the effect of delta restoration on the travel time and pathways of particles representing larval suckers under one complete set of observed boundary conditions. Overall retention was least for the prerestoration shoreline, and increased with the first phase of restoration when the northern delta was reconnected, because particles were forced to take longer pathways and to undergo more dispersal when leaving the river channel only on the north side. Retention decreased with the second phase of restoration, as particles were able to take "shortcuts" through the southern delta to the lake, but transport overall was slower and retention greater than occurred when the pre-restoration shoreline configuration was used.

Similarly, simulations were completed using three starting lake elevations in order to compare the simulated results from 2009 to simulated results based on the assumption that all boundary conditions were the same, but that lake elevation was either higher (such that it reached full pool at the maximum elevation during the simulation) or lower (by 0.25 meters) than was actually the case in 2009. The purpose of the comparison was to determine the effect of lake elevation, through a reasonable range, on the travel time and pathways of particles representing larval suckers, and ultimately on their retention in the lake, under one complete set of observed boundary conditions. When the lake was simulated near full pool, more particles left the river channel early and took direct paths through the southern delta, so overall retention decreased and travel times, particularly to points south, decreased compared to the simulation using the measured lake elevation. When the lake was simulated at a lower-than-measured elevation in 2009, access to the delta on both the north and the south side of the channel was more restricted than it was under the measured lake elevation, so more particles remained in the river channel and moved relatively quickly into the lake. As a result, overall retention decreased and travel times, particularly to points south, decreased compared to those in the simulation using the measured lake elevation. Retention, therefore, decreased at lake elevations both higher and lower than those measured in 2009, suggesting that retention in the lake is maximized at some intermediate elevation. 
Simulated larval lengths as determined by an empirically derived length-at-age relation were compared to measured lengths of larvae caught in three gear types (pop nets, larval trawls, and plankton nets) throughout the Williamson River Delta and along the eastern shoreline of the lake. The purpose was to validate the hydrodynamic and individual-based model used to simulate larval transport and to determine whether comparison with field data could provide guidance as to which dispersal scenarios were more likely to accurately represent larval behavior. Pearson $\mathrm{R}$ values for the various dispersal scenarios varied from 0.21 to 0.46 ; all were significant ( $\mathrm{p}$ less than or equal to 0.0169 ), and the highest correlation occurred with simulations obtained assuming completely passive dispersal.

Because gear types probably had their own inherent bias, we parsed the data by gear type and repeated the correlation analysis with simulated data based on the various dispersal scenarios. The comparison with pop net data showed the greatest bias between measurements and simulations (simulated lengths shorter by 1.3-1.4 millimeters [mm]) and the comparison with plankton net data showed the smallest bias (simulated lengths longer by $0.1 \mathrm{~mm}$ to shorter by $0.3 \mathrm{~mm}$ ) across the various dispersal scenarios. Further, we parsed the data by size of fish - small $(<13 \mathrm{~mm})$, medium $(13 \leq$ length $<16 \mathrm{~mm})$ and large $(16 \leq$ length $<19 \mathrm{~mm})$. The highest correlations with simulations were obtained for the medium size class $(\mathrm{R}=0.07-0.39$ and simulated lengths shorter by $0.7-0.9 \mathrm{~mm}$ ) and the smallest size class $(\mathrm{R}=0.26-0.31$ and simulated lengths longer by $0.5-0.8 \mathrm{~mm}$ ). By performing the correlation analysis based on particles entering the lake before and after June 2, we roughly parsed the data by species, because Lost River sucker larvae tend to enter the lake prior to shortnose sucker larvae. The correlation with simulated lengths was higher when restricted to particles entering the lake after June 2, indicating that the simulations were better at describing the dispersal of shortnose sucker larvae, that the field sampling was worse at describing Lost River sucker larvae, or both. When all correlation results were considered, there was no compelling evidence that any of the active dispersal scenarios resulted in a better or worse description of larval dispersal than any other scenario, including the passive dispersal scenario.

Our simulations showed that after leaving the delta, particle travel time and retention were affected by wind speed and direction, lake elevation, and simulated behavior, and that a hydrodynamic model in combination with individual-based models of behavior could potentially simulate the complex response of larval transport to the interaction of these factors. The model was validated with moderate success using net catches, as indicated by moderately strong $\mathrm{R}$ values that were often significant. Despite the uncertainties in efficiencies and bias in the various gear types, the unknown aspects of larval behavior and mortality, and the fact that the sucker larvae occur at very low densities in the lake and delta, this study, nonetheless, demonstrated that the model can reproduce overall patterns in larval sucker distribution. This approach could be useful for designing sampling strategies, investigating the effects of climate and hydrologic variability on sucker dispersal, and designing scenarios for lake management to maximize larval retention.

\section{Acknowledgments}

Matt Abel, Ernest Chen, Nathan Harris, Anna Willard, Terra Kemper, James Latshaw, Randal Lodges, and Daniel T. Brown of the U.S. Geological Survey assisted in field collection for USGS. Assistance with The Nature Conservancy's larval fish sampling was provided by Carolyn Doehring, Ross Egenolf, Pam Kostka, Christopher Patterson, Ariel Patushnik, Melody Warner, and Carla Wise. Dave Simon and Mark Terwilliger led field collections and data management for the OSU collections with student assistants Sara Akins, G. Antonio Cordero, Jenna Gelardi, Jake Godfrey, Kirsten Heesacker, Cara Holem, Justin Huff, Mark Jansen, Thomas Litwin, Elizabeth Quimba, Tamal Reece, Autumn Smith, Kate Spangler, Kevin Stertz, and Dax Strubb.

This report was funded by the Bureau of Reclamation, U.S. Department of Interior.

\section{References Cited}

Ashford, J., La Mesa, M., Fach, B.A, Jones, C., and Everson, I., 2010, Testing early life connectivity using otolith chemistry and particle-tracking simulations: Canadian Journal of Fisheries and Aquatic Science, v. 67, p. 1303-1315.

Beletsky, D., Mason, D.M., Schwab, D.J., Rutherford, E.S., Janssen, J., Clapp, D.F., and Dettmers, J.M., 2007, Biophysical model of larval yellow perch advection and settlement in Lake Michigan: Journal of Great Lakes Research, v. 33, p. 842-866.

Best, D.J., and Fisher, N.I., 1979, Efficient simulation of the von Mises distribution: Applied Statistics, v. 28, p. $152-157$.

Blaxter, J.H.S., and Hunter, J.R., 1982, The biology of clupeoid fishes: Advances in Marine Biology, v. 20, p. 1-223.

Box, G.E.P., and Muller, M.E., 1958, A note on the generation of random normal deviates: Annals of Mathematical Statistics, v. 29, p. 610-611. 
Bradbury, I.R., Gardiner, K., Snelgrove, P.V.R., Campana, S.E., Bentzen, P., and Guan, L., 2006, Larval transport, vertical distribution, and localized recruitment in anadromous rainbow smelt (Osmerus mordax): Canadian Journal of Fisheries and Aquatic Sciences, v. 63, p. 2822-2836.

Brickman, D., Adlandsvik, B., Thygesen, U., Parada, C., Rose, K., Hermann, A., and Edwards, K., 2008, Particle tracking, in North, E.W., Gallego, A., and Petitgas, P., eds., Manual of recommended practices for modeling physical-biological interactions during fish early life: International Council for Exploration of the Sea Cooperative Research Report no. 295, p. 14-31.

Burdick, S.M., and Brown, D.T., 2010, Distribution and condition of larval and juvenile Lost River and shortnose suckers in the Williamson River Delta restoration project and Upper Klamath Lake, Oregon - 2009 annual data summary: U.S. Geological Survey Open File Report 20101216, 78 p., http://pubs.usgs.gov/of/2010/1216/.

Casulli, Vincenzo, and Zanolli, P., 2002, Semi-implicit numerical modeling of nonhydrostatic free-surface flows for environmental problems: Mathematical and Computer Modelling, v. 36, p. 1131-1149.

Champalbert, G., and Marchand, J., 1994, Rheotaxis in larvae and juvenile sole (Solea solea L.) - Influence of light conditions and sediment: Journal of Experimental Marine Biology and Ecology, v. 177, p. 235-249.

Cooperman, M.S., and Markle, D.F., 2003, Rapid outmigration of Lost River and shortnose sucker larvae from in-river spawning beds to in-lake rearing grounds: Transactions of the American Fisheries Society, v. 132, p. 1138-1153.

Cooperman, M.S., and Markle, D.F., 2004, Abundance, size, and feeding success of larval shortnose and Lost River suckers from different habitats of the littoral zone of Upper Klamath Lake: Environmental Biology of Fishes, v. 71, no. 4, p. 365-377.

Cooperman, M.S., Markle, D.F., Terwilliger, Mark, and Simon, D.C., 2010, A production estimate approach to analyze habitat and weather effects on recruitment of two endangered freshwater fish: Canadian Journal of Fisheries and Aquatic Sciences, v. 67, p. 28-41.

Crandall, J.D., Bach, L.B., Rudd, Nathan, Stern, Mark, and Barry, Matt, 2008, Response of larval Lost River and shortnose suckers to wetland restoration at the Williamson River Delta, Oregon: Transactions of the American Fisheries Society, v. 137, p. 402-416.
Ellsworth, C.M., and Martin, B.A., 2012, Patterns of larval sucker emigration from the Sprague and lower Williamson Rivers of the Upper Klamath Basin, Oregon, after the removal of Chiloquin Dam-2009-10 annual report: U.S. Geological Survey Open-File Report 2012-1037, 34 p., http://pubs.usgs.gov/of/2012/1037/.

Ellsworth, C.M., Tyler, T.J., VanderKooi, S.P., and Markle, D.F., 2009, Patterns of larval sucker emigration from the Sprague and lower Williamson Rivers of the Upper Klamath Basin, Oregon, prior to the removal of Chiloquin Dam—2006 annual report: U.S. Geological Survey Open-File Report 2009-1027, 32 p., http://pubs.usgs.gov/ of/2009/1027/.)

Erdman, C.S., and Hendrixson, H.A., 2010, Larval Lost River and shortnose sucker response to large scale wetland restoration at the Williamson River Delta preserve-2009 annual data summary: Klamath Falls, Oreg., The Nature Conservancy, 38 p.

Hare, J.A., Churchill, J.H., Cowen, R.K., Berger, T., Cornillon, P., Dragos, P., Glenn, S., Govoni, J.J., and Lee, T.N., 2002, Routes and rates of larvae fish transport from the southwestern to the mid-Atlantic North American continental shelf: Limnology and Oceanography, v. 47, p. 1774-1789.

Helbig, J.A., and Pepin P., 1998, Partitioning the influence of physical processes on the estimation of ichthyoplankton mortality rates, I-Theory: Canadian Journal of Fisheries and Aquatic Sciences, v. 55, p. 2189-2205.

Hinckley, S., Megrey, B.A., and Miller, Thomas, 2009, Application 3-Recruitment prediction, in North, E.W., Gallego, Alejandro, and Petitgas, Pierre, eds., Manual of recommended practices for modelling physical-biological interactions during fish early life: International Council for Exploration of the Sea Cooperative Research Report no. 295, p. 106-113.

Hoff, G.R., Logan, D.J., and Markle, D.F., 1997, Otolith morphology and increment validation in young Lost River and shortnose suckers (Ostariophysi: Catostomidae): Transactions of the American Fisheries Society, v. 126, no. 3, p. 488-494.

Houde, E.D., and Bartsch, J., 2009, Mortality, in North, E.W., Gallego, Alejandro, and Petitgas, Pierre, eds., Manual of recommended practices for modelling physical-biological interactions during fish early life: International Council for Exploration of the Sea Cooperative Research Report no. 295, p. 27-42. 
Houde, E.D., and Zastrow, C.E., 1993, Ecosystem- and taxon-specific dynamic energetics properties of fish larvae assemblages: Bulletin of Marine Science, v. 53, no. 2, p. 290-335.

Irisson, Jean-Olivier, Leis, J.M., Paris, C.B., and Browman, H.I., 2009, Biological processes-Behavior and settlement, in North, E.W., Gallego, Alejandro, and Petitgas, Pierre, eds., Manual of recommended practices for modelling physical-biological interactions during fish early life: International Council for Exploration of the Sea Cooperative Research Report No. 295. p. 42-59.

Janney, E.C., Shively, R.S., Hayes, B.S., Barry, P.M., and Perkins, D., 2008, Demographic analysis of Lost River sucker and shortnose sucker populations in Upper Klamath Lake, Oregon: Transactions of the American Fisheries Society, v. 137, p. 1812-1825.

LaBolle, L.D., Jr., Li, H.W., and Mundy, B.C., 1985, Comparison of two samplers for quantitatively collecting larval fishes in upper littoral habitats: Journal of Fisheries Biology, v. 26, p. 139-146.

Leis, J.M., 2007, Behaviour as input for modelling dispersal of fish larvae-Behaviour, biogeography, hydrodynamics, ontogeny, physiology and phylogeny meet hydrography: Marine Ecology Progress Series, v. 347, p. 185-193.

Leis, J.M., and Carson-Ewart, B.M., 2003, Orientation of pelagic larvae of coral-reef fishes in the ocean: Marine Ecology Progress Series, v. 252, p. 239-253.

Leis, J.M., Hay, A.C., and Trnski, T., 2006, In situ ontogeny of behavior in pelagic larvae of three temperate, marine, demersal fishes: Marine Biology, v. 148, p. 655-669.

Mariani, Patrizio, MacKenzie, B.R., Iudicone, D., and Bozec, A., 2010, Modelling retention and dispersion mechanisms of bluefin tuna eggs and larvae in the northwest Mediterranean Sea: Progress in Oceanography, v. 86, p. $45-58$.

Markle, D.F., and Clauson, Kale, 2006, Ontogenetic and habitat-related changes in diet of late larval and juvenile suckers (Catostomidae) in Upper Klamath Lake, Oregon: Western North American Naturalist, v. 66, no. 4, p. 492-501.

Markle, D.F., and Dunsmoor, L.K., 2007, Effects of habitat volume and fathead minnow introduction on larval survival of two endangered sucker species in Upper Klamath Lake, Oregon: Transactions of the American Fisheries Society, v. 136, p. 567-579.
Markle, D.F., Reithel, S.A., Crandall, J., Wood, T., Tyler, T.J., Terwilliger, M., and Simon, D.C., 2009, Larval fish transport and retention and the importance of location for juvenile fish recruitment in Upper Klamath Lake, Oregon: Transactions of the American Fisheries Society, v. 138, p. 328-347.

Millar, R.B., and Fryer, R.J., 1999, Estimating the size selection curves of towed gears, traps, nets and hooks: Reviews in Fish Biology and Fisheries, v. 9, no. 1, p. 89-116.

Nahas, E.L., Jackson, G., Pattiaratchi, C.B., and Ivey, G.N., 2003, Hydrodynamic modeling of snapper Pagrus auratus egg and larval dispersal in Shark Bay, Western AustraliaReproductive isolation at a fine spatial scale: Marine Ecology Progress Series, v. 265, p. 213-226.

Overton, A.S., and Rulifson, R.A., 2007, Evaluation of plankton surface pushnets and oblique tows for comparing the catch of diadromous larval fish: Amsterdam, Fisheries Research, v. 86, p. 99-104.

Paris, C.B., Irisson, J.O., Lacroix, G., Fiksen, O., Leis, J.M., and Mullon, C., 2009, Application 2-Connectivity, in North, E.W., Gallego, Alejandro, and Petitgas, Pierre, eds., Manual of recommended practices for modelling physicalbiological interactions during fish early life: International Council for Exploration of the Sea Cooperative Research Report No. 295, p. 91-105.

Pepin, Pierre, Werner, Cisco, and van der Molen, Johan, 2009, Application 1-Adaptive sampling, in North, E.W., Gallego, Alejandro, and Petitgas, Pierre, eds., Manual of recommended practices for modelling physical-biological interactions during fish early life: International Council for Exploration of the Sea Cooperative Research Report No. 295, p. 87-90.

Reiser, D.W., Loftus, M., Chapin, D., Jeanes, E., and Oliver, K., 2001, Effects of water quality and lake level on the biology and habitat of selected fish species in Upper Klamath Lake-Report to the Bureau of Indian Affairs, Portland, Oreg.: Redmond, Wash., R2 Resource Consultants, Inc. [variously paged].

Reyns, N.B., Eggleston, D.B., and Luettich, R.A., Jr., 2006, Secondary dispersal of early juvenile blue crabs within a wind-driven estuary: Limnology and Oceanography, v. 51, no. 5, p. 1982-1995.

Ruetz, C.R., and Jennings, C.A., 2000, Swimming performance of larval robust redhorse Moxostoma robustum and low-velocity habitat modeling in the Oconee River, Georgia: Transactions of the American Fisheries Society, v. 129, p. 398-407. 
Scoppettone, G.G., and Vinyard, G., 1991, Life history and management of four endangered lacustrine suckers, in Minckley, W.L., and Deacon, J.E., eds., Battle against extinction-Active fish management in the American West: Tucson, Ariz., University of Arizona Press, p. 359-377.

Simon, D.C., Terwilliger, M.R., and Markle, D.F., 2009, Larval and juvenile ecology of Upper Klamath Lake suckers-2004-2008, Final report for contract 143403HWRU1584 submitted to U.S. Bureau of Reclamation, Klamath Falls, Oreg.: Corvallis, Oregon State University, Department of Fisheries and Wildlife, 174 p.

Terwilliger, M.R., Markle, D.F., and Kann, J., 2003, Associations between water quality and daily growth of juvenile shortnose and Lost River suckers in Upper Klamath Lake, Oregon: Transactions of the American Fisheries Society, v. 132, p. 691-708.

Terwilliger. M.R., Reece, T., and Markle, D.F., 2010, Historic and recent age structure and growth of endangered Lost River and shortnose suckers in Upper Klamath Lake, Oregon: Environmental Biology of Fishes, v. 89, p. 239-252.

Trnski, T., 2002, Behavior of settlement-stage larvae of fishes with an estuarine juvenile phase - In situ observations in a warm-temperate estuary: Marine Ecology Progress Series 242, p. 205-214.

Voss, R., and Hinrichsen, H.-H., 2003. Sources of uncertainty in ichthyoplankton surveys-Modeling the influence of wind forcing and survey strategy on abundance estimates: Journal of Marine Systems, v. 43, p. 87-103.
Watson, J.R., Mitarai, S., Siegel, D.A., Caselle, J.E., Dong, C., and McWilliams, J.C., 2010, Realized and potential larval connectivity in the Southern California Bight: Marine Ecology Progress Series, v. 401, p. 31-48.

Wesp, H.M., and Gibb, A.C., 2003, Do endangered razorback suckers have poor larval escape performance relative to introduced rainbow trout?: Transactions of the American Fisheries Society. v. 132, p. 1166-1178.

Wood, T.M., 2012, Dependence of flow and transport through the Williamson River Delta, Upper Klamath Lake, Oregon, on wind, river inflow, and lake elevation: U.S. Geological Survey Scientific Investigations Report 2012-5004, 32 p., http://pubs.usgs.gov/sir/2012/5004/.

Wood, T.M., Cheng, R.T., Gartner, J.W., Hoilman, G.R., Lindenberg, M.K., and Wellman, R.E., 2008, Modeling hydrodynamics and heat transport in Upper Klamath Lake, Oregon, and implications for water quality: U.S. Geological Survey Scientific Investigations Report 2008-5076, 48 p., http://pubs.usgs.gov/sir/2008/5076/.

Wood, T.M., Hendrixson, H.A., Markle, D.F., Erdman, C.S., Burdick, S.M., Ellsworth, C.M., and Buccola, N.L., 2012, Dispersal of larval suckers at the Williamson River Delta, Upper Klamath Lake, Oregon, 2006-09: U.S. Geological Survey Scientific Investigations Report 2012-5016, 28 p., http://pubs.usgs.gov/sir/2012/5016/. 


\section{Appendix A. Animations of Particle Tracking Simulations, May 16-June 4, 2009}

Videos in .AVI format are available for download at http://pubs.usgs.gov/sir/2013/5194/.

\section{Travel times at three starting lake elevations:}

Scenario C.-Animation of particle tracking simulation between May 16 and June 4, 2009. Dispersal of particles is by random swimming with nighttime only drift in the Williamson River channel. The starting elevation of the lake is as measured in 2009.

Scenario C-.--Animation of particle tracking simulation between May 16 and June 4, 2009. Dispersal of particles is by random swimming with nighttime only drift in the Williamson River channel. The starting elevation of the lake is $0.25 \mathrm{~m}$ below measured elevation in 2009 (Scenario C).

Scenario C+.- Animation of particle tracking simulation between May 16 and June 4, 2009. Dispersal of particles is by random swimming with nighttime only drift in the Williamson River channel. The starting elevation of the lake is $0.19 \mathrm{~m}$ above measured elevation in 2009 (Scenario C).

\section{Travel times at three shoreline configurations:}

Scenario C 2007.-Animation of particle tracking simulation between May 16 and June 4, 2009. Dispersal of particles is by random swimming with nighttime only drift in the Williamson River channel. The shoreline configuration is as it was in 2007 prior to the start of restoration at the Williamson River delta.

Scenario C 2008.-Animation of particle tracking simulation between May 16 and June 4, 2009. Dispersal of particles is by random swimming with nighttime only drift in the Williamson River channel. The shoreline configuration is as it was in 2008 after the first phase of restoration was completed and the northern part of the Williamson River delta (Tulana) was reconnected to Upper Klamath and Agency Lakes.

Scenario C.-Animation of particle tracking simulation between May 16 and June 4, 2009. Dispersal of particles is by random swimming with nighttime only drift in the Williamson River channel. The shoreline configuration as it existed starting in 2009 after restoration was completed and both the northern (Tulana) and southern (Goose Bay) parts of the Williamson River delta were reconnected to Upper Klamath and Agency Lakes. 

Publishing support provided by the U.S. Geological Survey Publishing Network, Tacoma Publishing Service Center

For more information concerning the research in this report, contact the Director, Oregon Water Science Center

U.S. Geological Survey

2130 SW 5th Avenue

Portland, Oregon 97201

http://or.water.usgs.gov 
